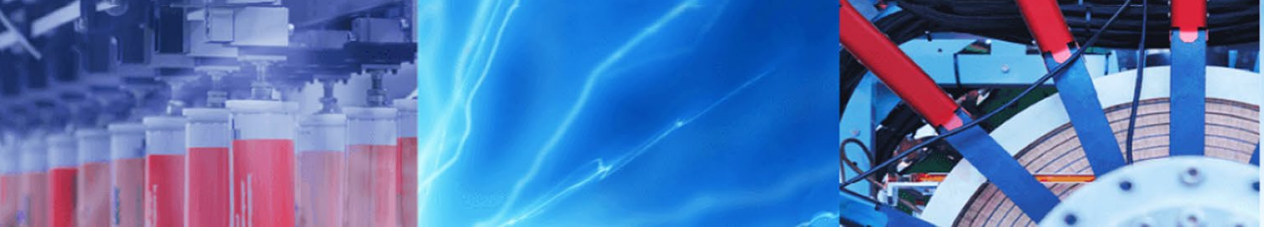

Research Article

\title{
Irrigation-based agricultural intensification and future groundwater potentiality: experience of Indian states
}

\author{
Bidur Paria ${ }^{1} \cdot$ Amartya Pani $^{1} \cdot$ Pulak Mishra ${ }^{1} \cdot$ Bhagirath Behera ${ }^{1}$
}

Received: 14 October 2020 / Accepted: 23 February 2021 / Published online: 12 March 2021

(C) The Author(s) 2021 OPEN

\begin{abstract}
While access to assured irrigation is a prerequisite for sustainable agricultural intensification, increasing use of groundwater for the same and decreasing areas under surface irrigation are expected to cause considerable hydro-ecological imbalance and hence serious concerns for sustainability. Importantly, the extent, nature, efficiency and impact of irrigation vary across regions depending on the geophysical and agro-climatic conditions, farming practices and socioeconomic setup. Nevertheless, it is suggested that appropriate crop diversification coupled with necessary policy and institutional supports can potentially reduce pressure on groundwater and make intensification in agriculture sustainable. Given this backdrop, this paper examines impact of irrigation and crop diversification on agricultural intensification and its implications for future groundwater dynamics in major Indian states. Using secondary data and applying panel data regression techniques for the period 1990-1991 to 2014-2015, the paper finds that both greater irrigation facilities and diversified crop basket increase cropping intensity. Similarly, use of more chemical fertilizers and higher yield also influence cropping intensity positively. However, rainfall variations and share of GSDP in agriculture have no significant impact. Based on the literature review and the above findings as well as using the insights from the informal interactions and random discussion carried out with the farmers and others stakeholders (e.g., researchers, community workers, extension service providers, NGO, etc.), the fuzzy cognitive models show that future policies and institutions should focus on improvement in agricultural systems and promoting surface irrigation. Besides, conservation and harvesting of rainwater, efficient functioning of the user groups, judicious use of chemical fertilizers and emphasis on cultivation of less water-intensive crops would also be crucial in this regard.
\end{abstract}

Keywords Irrigation - Groundwater · Cropping intensity · Agricultural intensification · Crop diversification . Sustainability $\cdot$ Panel data $\cdot$ Fuzzy cognitive modeling $\cdot$ India

\section{Introduction}

With agriculture employing more than 50 percent of the workforce and contributing to around 18 percent of GDP, ${ }^{1}$ its significance for achieving India's food security and socioeconomic development continues. Since the rate of

\footnotetext{
1 See Economic Survey 2017-18, Ministry of Finance, Government of India.
}

growth of population per annum is projected to be about 1.6 percent in the next two to three decades [19] and more than 80 percent of total poor living in rural areas [21], importance of the sector increases further [18]. Accordingly, emphasis has been given on promoting sustainable and inclusive intensification and improving productivity

Bidur Paria, pariabidurf@gmail.com; Amartya Pani, amartya.geo@gmail.com; Pulak Mishra, pmishra@hss.iitkgp.ac.in; Bhagirath Behera, bhagirath9@gmail.com | 'Department of Humanities and Social Sciences, Indian Institute of Technology Kharagpur, Kharagpur, West Bengal 721302, India. 
in Indian agriculture to meet additional requirements for foods and livelihoods. Nonetheless, this is a challenging task given the limited scope of expanding cultivable land including various geophysical and technological constraints and socioeconomic complexities.

It is recognized that development of ecofriendly irrigation system is imperative for increasing cropping intensity and accelerating growth of agriculture on sustained basis [50]. This is particularly so because diverse agroecological settings and farming practices have resulted in a very complex agricultural system and thus innumerable challenges for its sustainability [2]. For example, while the Green Revolution technologies, especially use of high yielding variety (HYV) seeds and chemical fertilizers, led to high rate of agricultural growth in the Green Revolution region, assured irrigation was a prerequisite for the success of these technologies [71]. This eventually created considerable pressure on groundwater level in the area. ${ }^{2}$ Over the years, several important policy measures were taken for surface water irrigation in many parts of India, but depletion of groundwater continues primarily because of its easy access and use as the main source for irrigation and drinking [82]. In addition, availability of credit and subsidy on other critical inputs such as irrigation equipment and power have also facilitated groundwater-based irrigation (Planning [57]).

The situation has become more alarming in recent years because of climate change, frequent droughts, irregular rains and floods. The effects of such climatic shocks and natural calamities on farm production, land use patterns and freshwater systems are well documented in the literature (e.g., $[34,53])$. It is found that, with an increase in temperature by $1{ }^{\circ} \mathrm{C}$, the requirement for water rises by 10 percent and this can have serious implications for crop productivity and water use efficiency [42]. Accordingly, farmers are being encouraged to cultivate less waterintensive crops and use various water-saving irrigation technologies to bring in rationality in water use. This is crucial in the rainfed regions that have the largest share of the poor and the crises are likely to be aggravated further therein with increasing use of modern inputs (e.g., genetically modified seeds, bio-fertilizers and pesticides) and climatic variations.

Thus, there are two critical but challenging requirements to accelerate sustainable agricultural intensification-(i) enhancing productivity of land and irrigation [86] and (ii) balancing water utilization with its potential [20, 39]. In either case, appropriate groundwater management

\footnotetext{
2 Use of groundwater has also increased by manifolds in different parts of India with increasing urbanization, industrialization and climate change [30].
}

is imperative to minimize the detrimental impacts on aquifers [30], as focusing only on water conservation has its own limitations in the long run. In particular, water use efficiency through appropriate crop choice and farming practices would be crucial in areas that suffer from the problem of severe water scarcity [48]. Further, with growing reliance on groundwater and declining areas under surface irrigation, crop diversification emerges as an important strategy to rationalize water use in agriculture and mitigate production-related risks. ${ }^{3}$ It is suggested that appropriate mix of crops can potentially reduce the pressure on groundwater $[75,76]$. In addition, crop diversification can also lead to more rational use of water and increase irrigation productivity. Accordingly, cultivation of appropriate combinations of crops using drip/sprinkler irrigation with piped water, better agricultural management practices have emerged as priorities in many parts of India ${ }^{4}$ [59].

Hence, facilitating both efficient irrigation and appropriate crop diversification are the key to promote sustainable intensification in Indian agriculture and appropriate policies and institutional interventions are crucial for the same. However, design and implementation of such intervention strategies require deeper and systematic investigation of the relationships among irrigation intensity, crop diversification and agricultural intensification and their implications for future groundwater dynamics. Nevertheless, in order to facilitate diversification of crops, the irrigation system should be able to respond to the changing water requirements throughout the year so that the farmers can adopt market-oriented approach and reallocate water from traditional crops to fruits and vegetables that are less water intensive [65]. However, facilitating such a shift requires making cultivation of these crops more profitable and thus increasing the opportunity costs of water used for the traditional crops. This is crucial given that continuous depletion of groundwater tables due to input-intensive cultivation of traditional crops makes water harvesting expensive [82].

This paper attempts toward modeling such relationships for major Indian states. Alternatively, the objective of the paper is to examine how irrigation in conjunction with crop diversification influences cropping intensity under diverse agro-climatic, social and economic conditions, and the implications of the impacts for future groundwater dynamics in India. Since the policies and other interventions often focus on increasing irrigation facilities without adequate consideration of their efficiency and

\footnotetext{
${ }^{3}$ In addition, crop diversification reduces market-related risks as well.

4 There are evidences of improvement in water use efficiency and crop productivity through micro-irrigation systems [35].
} 
sustainability [84], findings of this paper would provide useful insights for fine-tuning of the existing approaches. This is important considering the need for changes in the knowledge base, policies and practices in Indian agriculture in the recent past [68]. Accordingly, the paper broadly focuses on understanding the changes and suggesting the pathways to facilitate agricultural intensification in India that would be both socially inclusive as well as ecologically sustainable.

The paper has four sections. Discussion on the overall methodological approach along with the specific tools and techniques and sources of data is given in the next section. This section also gives a broad overview of the state-wise agro-climatic conditions and the extent of water used in agriculture along with selected village experiences for justification of the fuzzy cognitive modeling. The third section presents and analyzes the findings. Besides, this section designs three intervention scenarios in respect of policies, technologies and practices and examines the potential changes in water productivity in agriculture. The last section summarizes the major findings and highlights the necessary interventions in respect of policies and institutional arrangements.

\section{Methodology, data sources and selection of study area}

\subsection{Methodological approach}

\subsubsection{Simpson diversification index}

The paper is based on three major variables, viz. the cropping intensity, Simpson diversification index ${ }^{5}$ and irrigation intensity. The Simpson diversification index is defined as $D I_{j t}=1-\sum_{i=1}^{m} s_{i j t^{2}}^{2}$. Here, $D I_{j t}$ refers to the crop diversification index for state $j$ in the year $t$ and $s_{i j t}$ represents share of the ith crop in state $j$ 's gross cropped area in the year $t$.

\subsubsection{Panel data analysis}

The impact of irrigation and crop diversification on agricultural intensification is examined systematically by estimating panel data models and controlling the influence of other aspects such as variations in rainfall, use of chemical fertilizers, yield and share of GSDP in agriculture. Accordingly, the following functional relationship is specified:

Cropping Intensity $=f$ (Rainfall Variations, Irrigation Intensity, Use of Fertilizer, Share of GSDP in Agriculture, Yield, Crop Diversification)

$\overline{5}$ This index has extensive use in the existing studies (e.g., [6].
Here, irrigation and fertilizers capture the influence of technologies, whereas rainfall variations stand for the changes in climatic conditions. The variables yield and share of GSDP in agriculture control for the economic aspects. It is assumed that the variables like irrigation, fertilizer use and crop diversification would proxy for policy interventions as well. Similarly, crop diversification can capture mitigation of production- and marketrelated risks. Importantly, the relationships among the variables are likely to vary across the states and also over time depending on differences and/or changes in agroclimatic conditions, socioeconomic setup and policies and institutions. The following panel data model is specified to capture such variations (Eq. 1):

$$
\begin{aligned}
\ln \mathrm{Cl}_{i t}= & \beta_{0}+\beta_{1} \ln \mathrm{RIN}_{i t}+\beta_{2} \ln \mathrm{IRI}_{i t}+\beta_{3} \ln \mathrm{COF}_{i t} \\
& +\beta_{4} \ln \mathrm{GSDPAG}_{i t}+\beta_{5} \ln \mathrm{YILD}_{i t}+\beta_{6} \mathrm{CROPD}_{i t}+\epsilon_{i t}
\end{aligned}
$$

In panel data regression, $\epsilon_{i t}$ is a composite error term. It consists of two parts, viz. the individual specific error $\left(\alpha_{i}\right)$ and the other consisting of both time-series and cross-sectional component $\left(\eta_{i t}\right)$. Hence, $\epsilon_{i t}=\alpha_{i}+\eta_{i t}$ It is assumed that $\mathrm{E}\left(X_{i t}, \eta_{i t}\right)=0$, i.e., $\eta_{i t}$ is not correlated with $X_{i t}$ though $\alpha_{i}$ is correlated with $X_{i t}$ in Fixed Effects Model (FEM) (Gujarati \& Sangeetha 2007). However, in Random Effects Model (REM), the cross-sectional intercepts are drawn randomly from a much bigger population leading to no correlation between $\alpha_{i}$ and $X_{i t}$ i.e., $\mathrm{E}\left(X_{i t}, \alpha_{i}\right)=0$.

The overall methodological approach adopted in the paper and the steps followed in panel data modeling are presented in Fig. 1a and b, respectively. The appropriate model is selected through several statistical tests in STATA as mentioned in Fig. 1b. Based on the statistically significant explanatory variables in the panel data model and the insights from the literature, field visits and informal interactions with different stakeholders and participants in the workshops, the FCM is carried out. The design of the FCM and adjustments to the control variables are made to get different scenarios using the Mental Modeler software to reflect the outcomes and the implications of different policy measures for sustainability. Thus, the scenario building approach in FCM helps in deeper understanding of the groundwater-related problems and linking them to its potentials. Besides, the FCM also substantiates the findings of the panel data modeling.

\subsubsection{Fuzzy cognitive modeling}

The FCM is a generic modeling approach based on several assumptions. These assumptions, particularly in respect of symmetric and monotonic causal relations between concepts may limit the robustness of the FCM. Nevertheless, the FCM is popular for modeling interactions across sustainable 

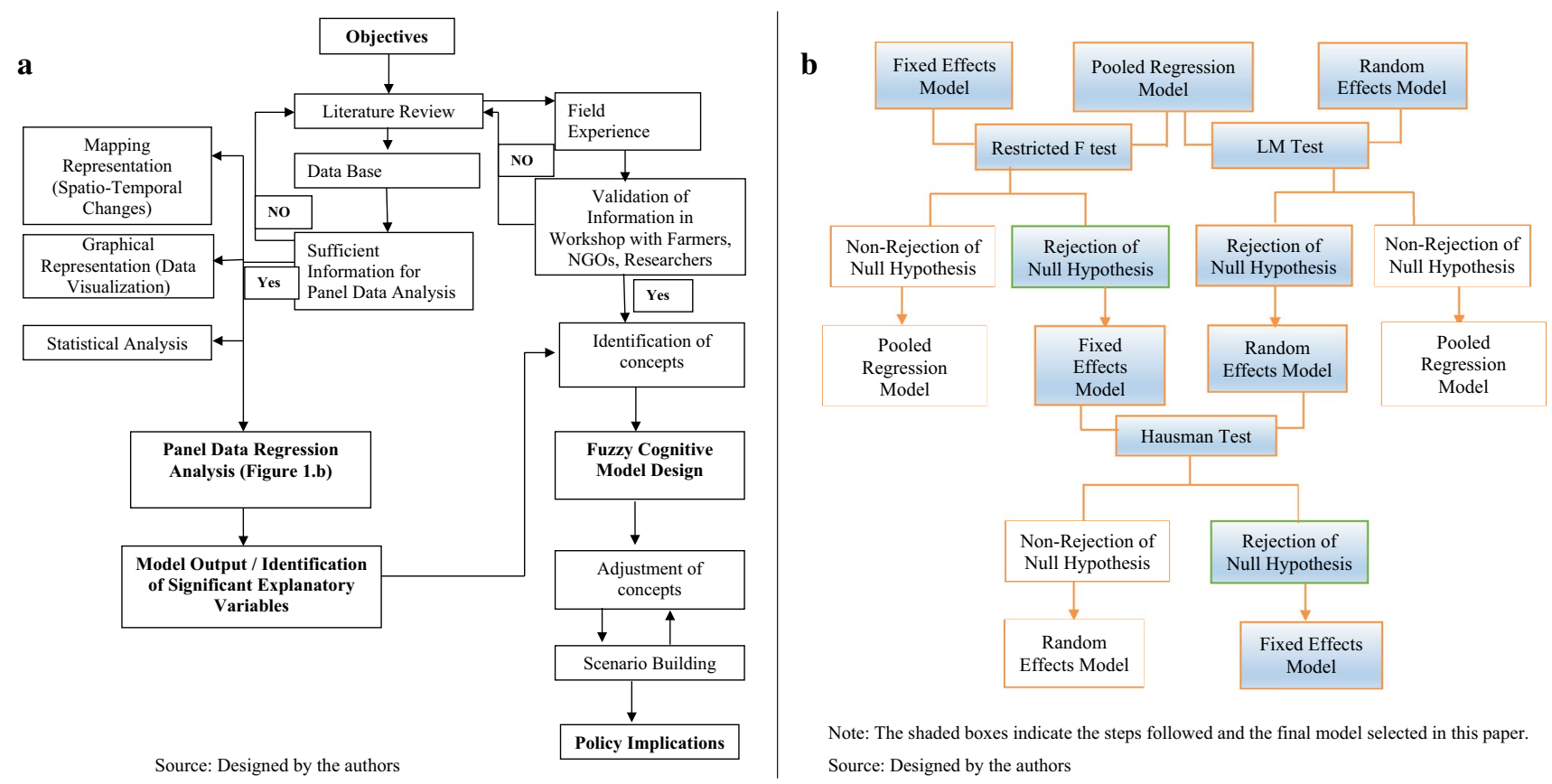

Note: The shaded boxes indicate the steps followed and the final model selected in this paper. Source: Designed by the authors

Fig. 1 a Flowchart of methodological approach to the present study Source Designed by the authors, b flow diagram of regression with panel data Note The shaded boxes indicate the steps followed and the final model selected in this paper. Source Designed by the authors

components given the failure of other computational methods to design such delicate mathematical structure [41]. In addition, this is an operational extension which always attains equilibrium to control unknown aspects [37]. In their study, VanVliet et al., [85] used both quantitative and semi qualitative methods like the FCM for designing scenarios in participatory development framework. Similarly, [36] designed models on policies for water management based on the FCM. According to Salmeron [78], the FCM can be very effective problem-solving technique for uncertain, small and incomplete dataset. However, it can be designed using expert views and information from different sources [60].

Broadly, the FCM uses concepts $C_{i}(i=1,2 \ldots n)$ and the interaction between $C_{i}$ and $C_{j}$ is assigned a weight $\left(w_{i j}\right)$ with a value from -1 to +1 to represent the causal relationship between them. The sign of $w_{i j}$ represents the nature of causality. While a $w_{i j}>0$ represents positive causality between $C_{i}$ and $C_{j}$, a $w_{i j}<0$ implies negative association between the two A weight of $w_{i j}=0$ suggests zero causality between $C_{i}$ and $C_{j}$ [44]. Besides, there is also a concept value $A_{i}$ derived from transformation of numeric number assigned by experts in the interval $[0,1][31]$. Each $A_{i}$ computes the impact on other concepts based on the inference rules [78]. The inference rules of Kosko, modified Kosko and rescale as shown below are commonly used for such simulations.

$$
\begin{aligned}
& A_{i}(k+1)=f\left(\sum_{j=1, j \neq 1}^{N} w_{j i} \times A_{j}(k)\right) \\
& A_{i}(k+1)=f\left(A_{i}(k)+\sum_{j=1, j \neq 1}^{N} w_{j i} \times A_{j}(k)\right) \\
& A_{i}(k+1)=A_{i}(k+1) \\
& =f\left(\left(2 \times A_{i}(k)-1\right)+\sum_{j=1, j \neq 1}^{N} w_{j i} \times\left(2 \times A_{j}(k)-1\right)\right)
\end{aligned}
$$

Here, $A_{i}(k+1)$ and $A_{i}(k)$ are the concept values for simulation step $(k+1)$ and $k$, respectively. Further, $k$ represents the index of interaction at every simulation step and $f$ (·) stands for the threshold (activation) function that can be (a) bivalent, (b) trivalent, (c) sigmoid or (d) hyperbolic as shown below.

$f(x)= \begin{cases}1, & x>0 \\ 0, & x \leq 0\end{cases}$
$f(x)= \begin{cases}1 & x>0 \\ 0 & x=0 \\ -1 & x<0\end{cases}$ 
Table 1 Sources of secondary data

\begin{tabular}{|c|c|c|c|}
\hline Variable & Unit of measurement & Source & Site \\
\hline Gross crop area & Thousand hectare & \multirow{4}{*}{$\begin{array}{l}\text { Ministry of Agriculture and Farmers } \\
\text { Welfare, Government of India }\end{array}$} & \multirow{7}{*}{$\begin{array}{l}\text { https://m.rbi.org.in/Scripts/Annua } \\
\text { IPublications.aspx?head=Handb } \\
\text { ook+of+Statistics+on+India } \\
\text { n+States }\end{array}$} \\
\hline Net crop area & Thousand hectare & & \\
\hline Gross irrigated area & Thousand hectare & & \\
\hline Yield & Kg per hectare & & \\
\hline Gross state domestic product (GSDP) & Lakh (Rupee) & \multirow{2}{*}{$\begin{array}{l}\text { National Statistical Office, Ministry of } \\
\text { Statistics and Programme Imple- } \\
\text { mentation, Government of India }\end{array}$} & \\
\hline GSDP in agriculture & Lakh (Rupee) & & \\
\hline Consumption of fertilizer & Kg per hectare & $\begin{array}{l}\text { Agriculture statistics at a glance, } \\
\text { Ministry of Agriculture and Farmers } \\
\text { Welfare, Government of India }\end{array}$ & \\
\hline Rainfall & Millimeter & Indian Meteorological Department & https://www.indiastat.com \\
\hline Net groundwater availability & \multirow[t]{3}{*}{ ham (Hectare meter) } & \multirow{3}{*}{$\begin{array}{l}\text { Central Ground Water Board (CGWB), } \\
\text { Government of India }\end{array}$} & \multirow{3}{*}{$\begin{array}{l}\text { http://cgwb.gov.in/GW-data-acces } \\
\text { s.html }\end{array}$} \\
\hline Gross groundwater draft & & & \\
\hline $\begin{array}{l}\text { Groundwater availability for future } \\
\text { irrigation use }\end{array}$ & & & \\
\hline
\end{tabular}

Table 2 Computation of variables

\begin{tabular}{lll}
\hline Variables & Unit of measurement & Definition \\
\hline Cropping intensity (CI) & In natural logarithmic scale & Percentage share of gross cropped area in net cropped area \\
Irrigation intensity (IRI) & In natural logarithmic scale & Percentage share of gross irrigated area in gross cropped area \\
Rainfall variations (RIN) & In natural logarithmic scale & Coefficient of variation of rainfall (CV) \\
Consumption of fertilizer (COF) & In natural logarithmic scale & Natural logarithm of use of fertilizers per hectare \\
Share of agriculture in GSDP (GSDPAG) & In natural logarithmic scale & Percentage share of GSDP from agriculture in total GSDP \\
Crop diversification (CROPD) & Index & Simpson diversification index \\
Yield (YILD) & In natural logarithmic scale & Natural logarithm of output per hectare
\end{tabular}

Authors' calculation using the data mentioned in Table 1

$f(x)=\frac{1}{1+e^{-\lambda x x}}$

$f(x)=\tanh (\lambda \times x)$

The $\lambda(>0)$ determines steepness of the respective function and $x$ represents equilibrium value of $A_{i}(k)$. If all the concepts belong to the interval $[0,1]$, appropriate threshold function will be sigmoid, whereas hyperbolic tangent function will be suitable when the value belongs to the interval $[-1,-1][41]$.

\subsection{Sources of data and information}

Mainly secondary data are used in this paper. The variable wise sources of secondary data are presented in Table 1. Based on these secondary data and necessary variables are computed (Table 2) for estimation of the panel data model with fifteen sample states for the period 1990-1991 and 2014-2015. Selection of these states and the time frame as well as identification of the variables for this modeling are based on GIS mapping of agro-climatic conditions and changes in cropping intensity, irrigation intensity and crop diversification, visualization of spatiotemporal changes, and insights from the existing studies. Findings from the panel data modeling, insights from the literature, and objective, behavioral and perception specific inputs gathered through field visits, informal interactions and random discussion with diverse stakeholders are used subsequently for the fuzzy cognitive modeling (FCM).

Here, both the panel data analysis and FCM are largely guided by the insights from the informal discussion carried out in the selected study villages under the project Promoting Socially Inclusive and Sustainable Agricultural Intensification in West Bengal and Bangladesh (SIAGI) sponsored by the Australian Centre for International Agricultural Research (ACIAR). ${ }^{6}$ Researchers from The Commonwealth Scientific and Industrial Research Organization (Australia), The Australian National University, Edith Cowan University

$\overline{{ }^{6} \text { The details }}$ on the study SIAGI are available at https://siagi.org. 
Table 3 Water resources of India: an overview

\begin{tabular}{ll}
\hline Parameters & Amount \\
\hline Annual precipitation (Bm3) & 4000 \\
Available water resources (average flow) (Bm3) & 1869 \\
Utilizable water (Bm3) & 1123 \\
Share of utilizable water in available water resources (\%) & 60.08 \\
Surface water (storage and diversion) (Bm3) & 690 \\
Groundwater (replenishable) (Bm3) & 433 \\
Present utilization by source—surface water:groundwater (\%) & $65.21: 34.79$ \\
Net annual groundwater availability (Bm3) & 398 \\
Total annual groundwater recharge (Bm3) & 433 \\
Annual groundwater draft (Bm3) & 231 \\
Water use for irrigation (Bm3) & 688 \\
Water use for domestic purposes (Bm3) & 56 \\
Water use in industry, energy and other sectors (Bm3) & 69 \\
Total utilization for major purposes (Bm3) & 813 \\
Composition of use for major purposes—irrigation:domestic:others (\%) & $84.62: 6.89: 8.49$
\end{tabular}

Central water commission and national water academy, Government of India (2017)
(Australia), Indian Institute of Technology Kharagpur, Livelihood and Natural Resource Management Institute (India) and Bangladesh Agricultural University have been working with the NGOs partners PRADAN (India), Centre for Development of Human Initiatives (India) and Shushilan (Bangladesh) in this project. The project broadly aims at understanding different factors and the underlying risks that influence the changes, applying new engagement and assessment approaches and tools, and providing policy directions and pathways to facilitate agricultural intensification in West Bengal and Bangladesh that would be both socially inclusive as well as ecologically sustainable.

This in addition to secondary data, this paper also uses important insights drawn from the random discussion and the presentations by and interactions with the participants in the workshops and informal engagements with various stakeholders conducted under this project. The participants of these workshops and informal engagements included the researchers and development practitioners engaged in the SIAGI, research scholars from diverse disciplines of Indian Institute of Technology Kharagpur, farmers from the selected study villages from West Bengal, traders from the markets adjacent to these study villages, and development practitioners from PRADAN (India), Centre for Development of Human Initiatives (India) and Shushilan (Bangladesh).

\subsection{Selection of sample states}

Since the panel data modeling here aims at examining the relationships among cropping intensity, crop diversification and irrigation intensity, the sample sates are selected covering different agro-climatic zones of the country. This has special significance particularly considering the rainfall patterns and the groundwater situation. While the average annual rainfall in India is 300-650 $\mathrm{mm}$, potential for water availability is estimated to be about $1869 \mathrm{bcm}$. Water availability is the highest in the Brahmaputra basin $(537.24 \mathrm{bcm})$, followed by the Ganga Basin $(525.02 \mathrm{bcm})$. The Central Ground Water Board [12] has estimated that the annual renewable groundwater is around $447 \mathrm{bcm}$. However, water available per capita has decreased from $2210 \mathrm{~m}^{3} /$ year in 1991 to $1441 \mathrm{~m}^{3}$ /year in 2015 indicating possible water scarcity in the country in near future. Further, total Ultimate Irrigation Potential (UIP) is around 140 million hectares with the net sown area being 140,021 thousand hectares. Out of this, minor irrigation potential using surface water is only 17,337 hectares, whereas that with groundwater is 64092 hectares [13].

The major aspects of water resources in India are presented in Table 3. Although the current utilization of groundwater is still within the potential, it is largely used for irrigation. Around 85 percent of water used goes for irrigation purpose. Further, given the vast geographical area of the country with diverse agro-climatic conditions (Fig. 2), there are differences in irrigation intensity and hence extent of groundwater usage. Many of the regions have experienced rapid decrease in groundwater level in the recent past largely on account of irrigation. Hence, impact of irrigation on agricultural intensification and groundwater stock are likely to vary across the regions, and there is a need to capture such diversity through systematic analysis. Accordingly, this paper covers five different agro-climatic zones comprising fifteen states to capture such variations (Table 4). 


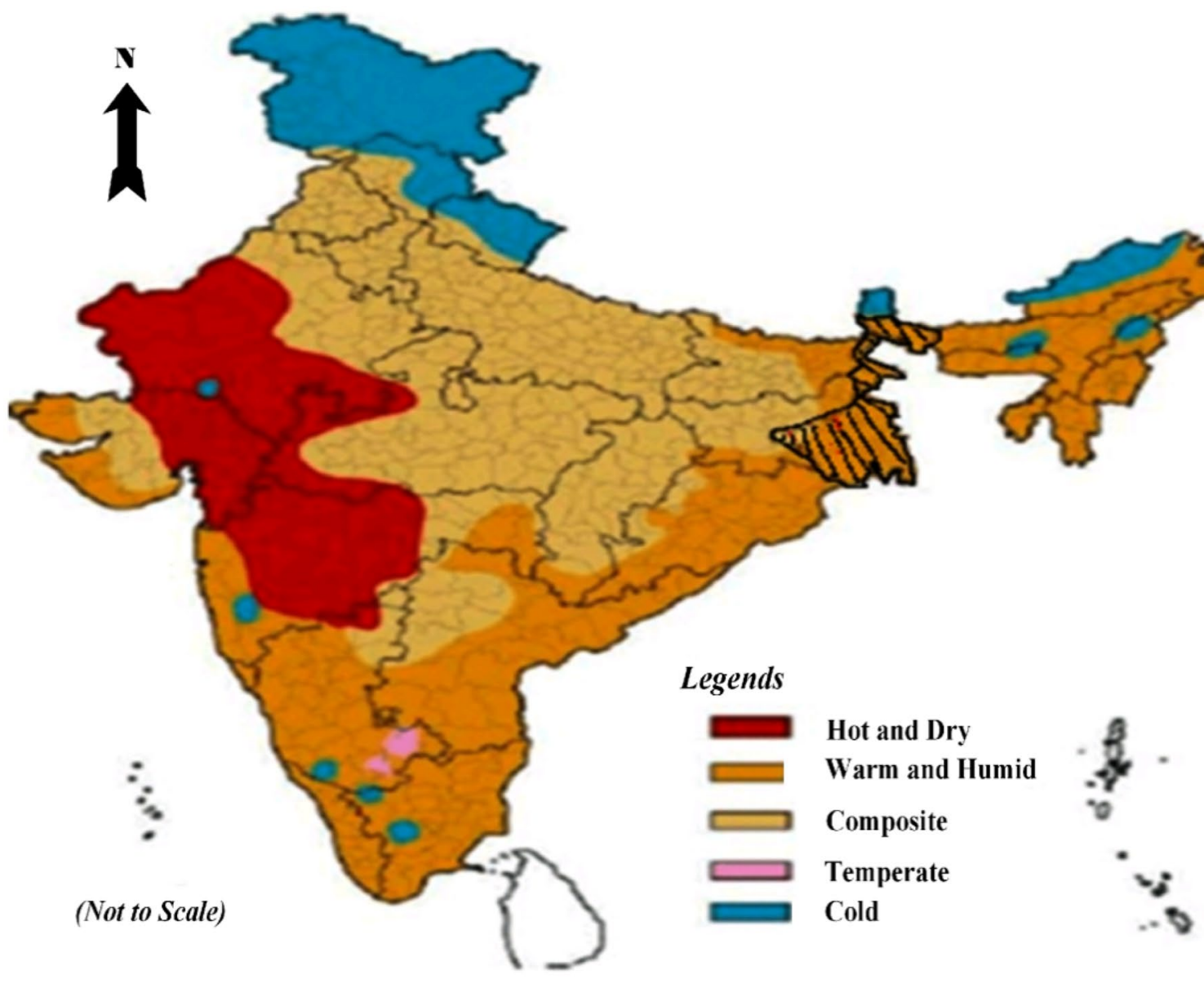

Source: www.indiamap.org

Fig. 2 Agro-climatic zones of India Source www.indiamap.org

Table 4 Agro-climatic conditions in the selected states. SourceBased on framework of the Indian Council of Agriculture Research (ICAR) available at www. icar. org.in

Here, majority of the selected states belong to warm and humid and composite agro-climatic zones. But, these states in general are agriculturally advanced (as compared to other India states) and have high cropping intensity indicating greater pressure on groundwater. Nevertheless, the study includes three states from hot and dry region to make the sample more comprehensive. It is expected that 
such coverage of states from diverse agro-climatic zones in the sample would make the findings robust.

\subsection{Selection of village for experiences in FCM formulation}

The two study villages selected for the SIAGI project are Dhalaguri and Uttar Chakoakheti located in Coochbehar and Alipurduar district, respectively, of West Bengal, India. While Alipurduar belongs to the agro-climatic zone of the Eastern Himalayan Region of the Lower Gangetic Plain, Coochbehar belongs to the Tarai agro-climatic zone of the southern tail of the sub-Himalayan West Bengal. Alipurduar has warm and humid climate with temperature varying from $38^{\circ} \mathrm{C}$ in summer to $6^{\circ} \mathrm{C}$ in winter with average rainfall of $350 \mathrm{cms}$. Topography of this district has a mixed hilly area and undulates a vast plain and the nature of soil varies from alluvial to sandy and hard black clayey [28]. On the other hand, Coochbehar has a flat topography with a slight southeastern slope and is dominated by fine loamy and coarse loamy soil. A highly humid atmosphere and abundant rains are the main characteristics of this district [70]. Insights from such diverse agro-climatic conditions of the two districts and the study villages located therein provide the necessary directions for modeling strategies for efficient groundwater management and sustainable intensification in agriculture in this paper.

\section{Results and discussion}

\subsection{Changes in irrigation intensity, crop diversification and agricultural intensification}

It is evident that appropriate farming practices can help in arresting the adverse impact of modern agricultural practices on ecology and economy [26]. For example, since sustainable agriculture requires less input-intensive methods [54], adoption of natural production processes would rationalize resource use [66]. However, while combining ecologically conducive agricultural systems with traditional farming practices would be imperative, the presence of many smallholder farmers in different parts of India may limit such transition [5]. Under these circumstances, crop diversification may become a useful strategy $[27,40],{ }^{7}$ particularly for reducing dependence on

\footnotetext{
7 Appropriate crop diversification can also increase agricultural income, provide employment, eradicate poverty, and conserve soil and water [61]. In addition, farmers and their families benefit from greater diversity in their diet and hence better nutrition.
}

monoculture cropping [65] and its influence on environmental degradation.

Furthermore, impact of crop diversification and irrigation on intensification is quite complex and ambiguous as it also depends on other factors such as crop types, seasons of cultivations, local agro-ecological conditions and policy and institutional supports. For instance, shifting from water-intensive crops (e.g., paddy or sugarcane) to pulses in Rabi season may not require much irrigation facilities leading to an inverse relationship between the two, whereas crop diversification from pulses to paddy or sugarcane season would require more irrigation. Similarly, the direction of association between crop diversification and cropping intensity is also unclear. For example, diversification from paddy/sugarcane to less water-intensive pulses or vegetables may result in larger cropping intensity (primarily due to less requirement of irrigation) and vice-versa.

Given this backdrop this sub-section examines the trends and variations in cropping intensity, crop diversification and irrigation intensity across major Indian states. The extent of diversification in crop basket varies widely across the selected states (Fig. 3). For example, it is very low in Assam, Odisha and West Bengal, but considerably high in Gujarat, Maharashtra, Karnataka and Madhya Pradesh. Even the state like Punjab that experienced Green Revolution lags behind many other states on this front. Similarly, there are variations in respect of cropping intensification and irrigation intensity as well across the states. Importantly, relative differences in respect of cropping intensity and crop diversification are also evident for many of the states. For example, West Bengal has cropping intensity as high as Punjab, but crop diversity is very low in the state. Similarly, although decreased over time, there are wide interstate differences in irrigation intensity vis-à-vis agricultural intensification and crop diversification. Thus, the impact of irrigation and crop diversification on cropping intensity appear to be misnomer possibly because of diverse agro-climatic conditions, policies, institutional supports, culture-driven farming practices and food consumption habits.

Differences in changes in the nature and extent of crop diversification across the states are also evident (Fig. 3). Such variations may largely be caused by both supply (e.g., technology, infrastructure, technology, relative income, rainfall resource disposal, institutional supports, etc.) as well as demand (e.g., urban population, per capita income, preferences, etc.)-related factors along with various external causes such as climate change [7]. It is commonly perceived that greater access to markets and improved communication networks (connectivity) can promote diversification toward growing high-value cash crops such as jute, potato, oilseeds and vegetables. Increase in per 

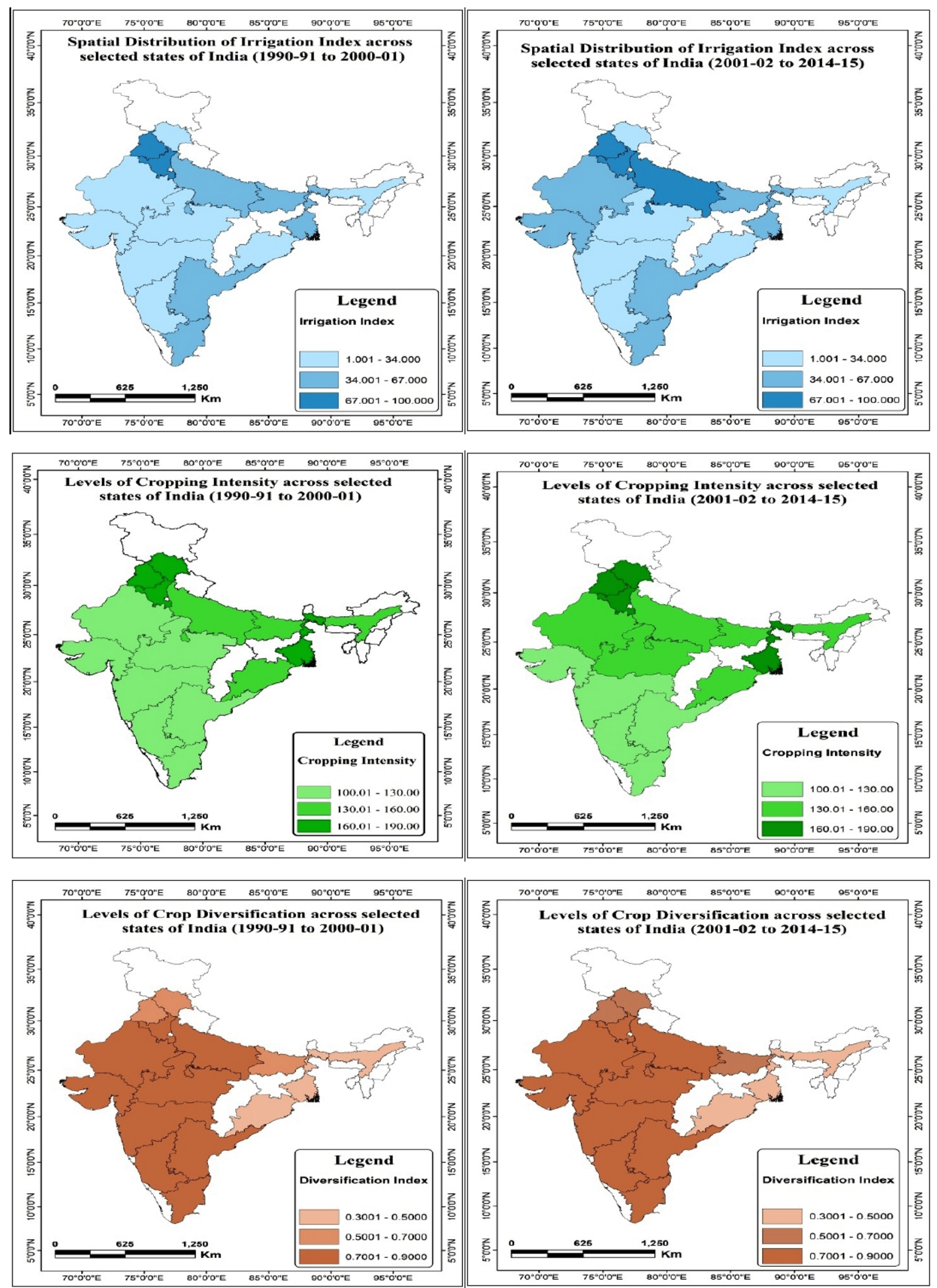

Source: By Authors using Arc GIS Pro

Fig. 3 Spatiotemporal changes in irrigation, crop diversification and intensification 


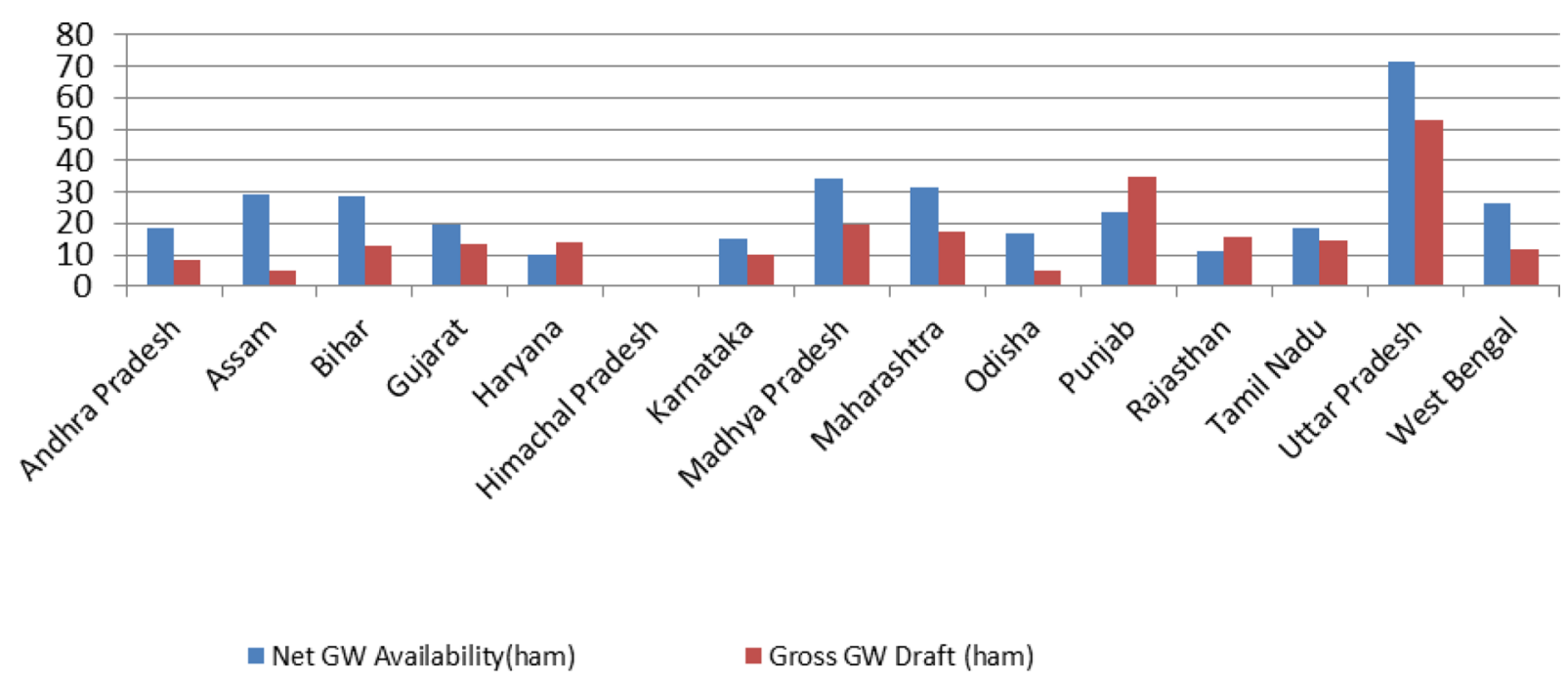

Source: Based on the data from $\underline{w w w . i n d i a s t a t . c o m ~}$

Fig. 4 Net groundwater availability and gross groundwater draft, 2014-2015

capita income can also enhance the ability and willingness of people to spend more on such high-value food crops and create their market. In addition, many northern and eastern Indian states, farmers were traditionally cultivating wheat and sugarcane. However, water draft regulation in the upper Ganga basin and policy interventions have shifted the focus toward less water and fertilizer intensive crops such as pulses and oilseeds widely. Besides, the states like Madhya Pradesh, Gujarat, Andhra Pradesh, Karnataka and Maharashtra have diversified crop basket for better water management practices along with its conservation, artificial recharge and integrated watershed development. Such differences in approaches and interventions have also les to the variations in crop diversification.

In this context, crop diversification can potentially balance available irrigation with cropping intensity. A diversified crop basket helps in coping with production risks [77]. ${ }^{8}$ For example, in many cases, pulses have been integral part of crop basket primarily because of their ability to stabilize nitrogen in soil, carbon sequestration, soil isolation and low water requirement [4]. ${ }^{9}$ In Indian context, Kar et al., [33] found that diversification in crop basket mitigates drought in upland areas, enhances water use

\footnotetext{
8 Such production risks are often caused by crop diseases, pests, varying weather conditions and irregular rainfall [46].

9 In addition to water, sustainable management of agricultural land restricts degradation in physical, chemical, biological and ecological features in soil [11].
}

efficiency and increases yield. Similarly, studies in Papua New Guinea [14] showed significant improvement in technical efficiency following crop diversification. Further, crop diversification in favor of non-food grains can also result in higher farm income and lower market-related risks [73]. ${ }^{10}$ Although it is more prevalent in commercial farms, interventions in respect of price protection, crop insurance, research and extension services, subsidized inputs, availability of technologies, etc., can promote crop diversification even in peasant farms $[38,51]$. In addition, availability of all-weather accessible roads, irrigation, electricity and market infrastructure are also necessary for changes in cropping patterns and crop diversification [38].

Nevertheless, increasing irrigation intensity seems to have resulted in excess pressure on groundwater. Figure 4 shows that Haryana, Punjab and Rajasthan recorded higher gross groundwater draft vis-à-vis the availability in 2014-2015. Notably, while Punjab and Haryana have high cropping intensity and the farmers following largescale input-intensive farming practices owing to the Green Revolution, Rajasthan has vast stretch of desert. What is more concerning is that irrigation intensity is higher than net groundwater availability for future irrigation in all the major Indian states except Assam (Fig. 5). In particular, the gap is quite wide in the Green Revolution region of Punjab, Haryana and Uttar Pradesh. It is also seen that some states like Assam, Karnataka, Madhya Pradesh and Maharashtra

\footnotetext{
10 Thus, diversification in crop basket can lower impact of associated risks [8].
} 


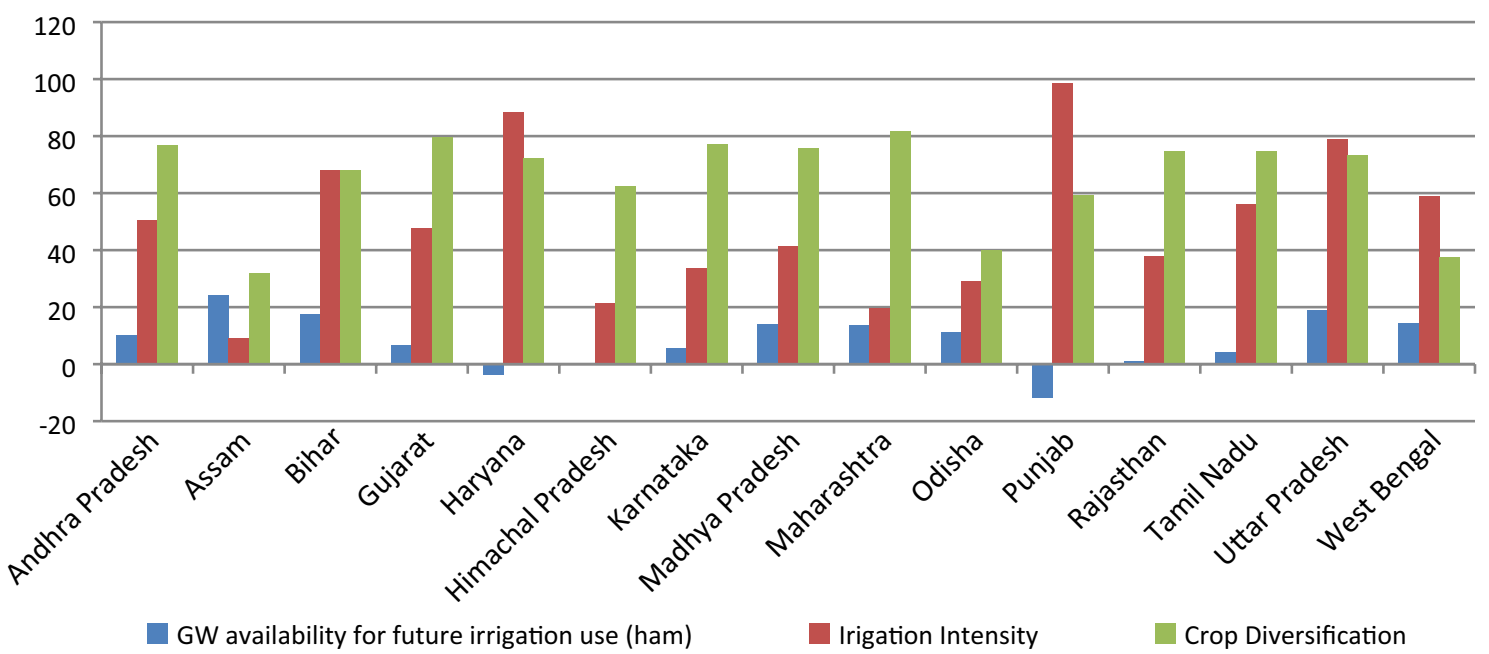

Source: Based on Agricultural Statistics at a Glance of the Directorate of Economics and

Statistics, Ministry of Agriculture (Government of India)

Fig. 5 Crop diversification, irrigation intensity and groundwater availability, 2014-2015

could bridge or narrow down the gaps through crop diversification.

Thus, the extent and changes in irrigation, cropping intensity and crop diversification and their relationships appear to be very complex and dynamic. Understanding the impact of irrigation and crop diversification on intensification in agriculture, therefore, requires systematic exploration in a dynamic context as well as controlling influence of other variables. The vision of climate justice requires actions to help resource poor farmers who are predicted to be adversely affected by climate. In many developing countries the design and operation of agricultural subsidies can be greatly improved, and the objectives need to be set within this broader policy framework [81]. Nevertheless, in order to design appropriate intervention strategies, it is necessary to systematically examine the impact of modern farming practices including irrigation and crop diversification on cropping intensity. The next sub-section of the paper attempts for the same through panel data modeling.

\subsection{Impact of irrigation and crop diversification on cropping intensity}

Based on the above discussion, the impact of irrigation and crop diversification on agricultural intensification is examined systematically by estimating panel data models and controlling the influence of other aspects such as variations in rainfall, use of chemical fertilizers, yield, crop diversification and share of GSDP in agriculture.
While selection of these variables is based on the framework for accelerating agricultural growth suggested by Behera and Mishra, [10], their potential influence is well documented in the literature. Broadly, intensification in Indian agriculture requires expansion of irrigation facilities, but this often leads to greater extraction of groundwater causing serious ecological threats. Intensification through diversification of crop basket can potentially rationalize water use in irrigation, enhance its efficiency and reduce production- and market-related risks [62]. While such a strategy can make intensification in agriculture profitable, socially inclusive and ecologically sustainable, the nature and extent of crop diversification are often influenced by geophysical setup, agro-climatic conditions, irrigation system, farming practices and various social, economic and institutional factors. Following Behera and Mishra [10], the

Table 5 Results of Levin-Lin-Chu panel unit-root test

\begin{tabular}{ll}
\hline Variables & Adjusted t-statistic \\
\hline Cropping intensity & $-2.0080^{* * *}$ \\
Rainfall variations & $-4.8120^{* * *}$ \\
Irrigation intensity & $-2.5315^{* * *}$ \\
Consumption of fertilizer & $-1.9352^{* *}$ \\
Share of GSDP in agriculture & $-6.5934^{* * *}$ \\
Yield & $-2.2318^{* *}$ \\
Crop diversification & $-3.4852^{* * *}$ \\
\hline
\end{tabular}

${ }^{* *}$ significant at 5 percent; ***significant at 1 percent 
Table 6 Results of panel data regression

\begin{tabular}{|c|c|c|c|c|c|c|}
\hline \multirow[t]{5}{*}{ Variable } & \multicolumn{6}{|c|}{ Estimated models } \\
\hline & \multicolumn{2}{|c|}{ Pooled regression model } & \multicolumn{2}{|c|}{ Random effect model } & \multicolumn{2}{|c|}{ Fixed effect model } \\
\hline & \multicolumn{6}{|c|}{ Methods of estimation (robust results) } \\
\hline & \multicolumn{2}{|c|}{ Ordinary least squares (OLS) method } & \multicolumn{2}{|c|}{$\begin{array}{l}\text { Generalized least squares (GLS) } \\
\text { method }\end{array}$} & \multicolumn{2}{|c|}{$\begin{array}{l}\text { Least squares dummy variable } \\
\text { (LSDV) method }\end{array}$} \\
\hline & Coefficient & t-statistic & Coefficient & z-statistic & Coefficient & t-statistic \\
\hline Rainfall variations & 0.0334 & 1.21 & 0.0025 & 0.12 & -0.0002 & -0.01 \\
\hline Irrigation intensity & 0.0628 & $4.54^{* * *}$ & 0.0649 & $4.73^{* * *}$ & 0.0672 & $4.81^{* * *}$ \\
\hline Consumption of fertilizers & -0.0328 & $-2.32 * *$ & 0.0209 & $2.08^{* *}$ & 0.0268 & $2.63^{* * *}$ \\
\hline Share of GSDP in agriculture & 0.1197 & $6.49^{* * *}$ & 0.0105 & 0.67 & 0.0067 & 0.42 \\
\hline Yield & 0.1359 & $8.09^{* * *}$ & 0.0533 & 3.03 & 0.0445 & $2.51^{* * *}$ \\
\hline Crop diversification & -0.5042 & $-12.07^{* * *}$ & 0.1245 & $1.41^{* * *}$ & 0.2656 & $2.78^{* * *}$ \\
\hline Constant & 3.6509 & $18.32^{* * *}$ & 4.0854 & $22.32^{* * *}$ & 4.0501 & $22.38^{* * *}$ \\
\hline F statistics & \multicolumn{2}{|c|}{$F(6,368)=63.96^{* * *}$} & \multicolumn{2}{|c|}{$\chi_{(6)}^{2}=94.76^{* * *}$} & \multicolumn{2}{|c|}{$F(6,354)=16.81^{* * *}$} \\
\hline Overall R square & \multicolumn{2}{|c|}{0.50} & \multicolumn{2}{|c|}{0.0484} & \multicolumn{2}{|c|}{0.0073} \\
\hline Within R square & & & \multicolumn{2}{|l|}{0.2171} & \multicolumn{2}{|l|}{0.2218} \\
\hline Between $\mathrm{R}$ square & & & 0.0396 & & 0.0032 & \\
\hline Number of observations & \multicolumn{6}{|l|}{375} \\
\hline Restricted F test & \multicolumn{6}{|c|}{$F(14,354)=147.80^{* * *}$} \\
\hline $\begin{array}{l}\text { Breusch and Pagan Lagrangian } \\
\text { multiplier test }\end{array}$ & \multicolumn{6}{|c|}{$\chi_{(6)}^{2}=2678.91^{* * *}$} \\
\hline Hausman test & \multicolumn{6}{|c|}{$\chi_{(6)}^{2}=15.38^{* *}$} \\
\hline Tests of endogeneity & \multicolumn{6}{|c|}{ Durbin (score) $\chi_{(1)}^{2}=0.249528$} \\
\hline & \multicolumn{6}{|c|}{ Wu-Hausman $F(1,371)=0.24703$} \\
\hline
\end{tabular}

${ }^{* *}$ significant at 5 percent; ${ }^{* * *}$ significant at 1 percent

model envisaged here is based on the premise that cropping intensity depends on economic, ecological (climatic), technological and policy aspects.

Since the present study uses the balance panel dataset of 15 states over 25 years, stationary nature of the variables is confirmed by carrying out Levin-Lin-Chu (2002) test for the presence of unit roots. Here, it is hypothesized that all the panels have a unit root and its rejection suggests stationary nature of at least one of the panels. The results are presented in Table 5 . The adjusted t statistics (with trends and panel-specific constants) confirm no presence of unit root.

This paper estimates both the FEM and the REM along with the pooled regression model. Table 6 presents the regression results. The appropriate model is chosen using statistical test as presented in Fig. $1 \mathrm{~b}$. While all the estimated models are statistically significant (Table 6), ${ }^{11}$ results

\footnotetext{
11 Table 6 also reports the results of the statistical tests for endogeneity. It is evident that the estimated models have no endogeneity problem. Further, low value of the variance inflation factors (VIFs) suggest no severe multicollinearity.
}

of these tests suggest that the FEM is best suited for the present dataset. Hence, statistical significance of the individual variables and their impact are analyzed using the results of the FEM. From the regression results of the FEM, it is evident that agricultural intensification is influenced directly by irrigation facilities, use of chemical fertilizers, yield and the extent of crop diversification. While higher irrigation intensity and greater use of chemical fertilizers facilitate agriculture intensification, higher extent of crop diversification widens scope for the same in respect of both production and market. More specifically, crop diversification facilitates intensification through mitigation of production- and market-related risks and creating new market opportunities. This eventually results in higher cropping intensity. Similarly, higher yield encourages farmers to increase intensification. In particular, higher yield encourages farmers toward greater intensification as it enhances the possibility of greater returns.

Thus, water availability through improved irrigation facilities and more use of chemical fertilizers facilitate multiple cropping and brings additional land under cultivation leading to greater intensification. Nevertheless, this may lead to excessive extraction of groundwater 
(this is particularly so as many chemical fertilizers require adequate water for their effective use) and hence pose threats to sustainability of the system [45]. Further, use of quality chemical fertilizers and proper skills are crucial for intensification [3], whereas efficiency becomes low and adverse effects are observed when marginal farmers use low quality fertilizers without having proper knowledge about the same.

However, the impact of rainfall variations on cropping intensity is not significant and hence surprising. In a recent study in Ghana by Kyei-Mensah [43], it is found that greater variations in the rainfall reduced both crop production and intensification. However, the variable may behave differently with rainwater harvesting, surface water irrigation and efficient infrastructure.

Thus, irrigation has significant impact on cropping intensity. Given the findings that increasing intensification requires greater irrigation facilities, more pressure on groundwater is very likely. In order to make the intensification sustainable, it is, therefore, necessary to assess existing groundwater potential and design strategies to enhance it further. However, since there are diversities on these facets across the states, deriving the policy directions from the findings requires scenario building under different context and exploring the potential relationships.

Existing studies suggest water use efficiency and productivity should be enhanced. According to Aggarwal [2], there is a need for appropriate policies and approaches to balance groundwater extraction with its recharge for sustainable and inclusive intensification. It is also realized that there should be greater emphasis on surface irrigation as the traditional sources like tanks, ponds and wetlands have largely been neglected with the advent of lift irrigation system, [15]. In order to restrict over-extraction of groundwater, these surface sources should be renovated and used in irrigation $[15,45]$. Restricting the depth of irrigation wells would also be crucial in this regard [74]. In addition, use of drip and sprinkler irrigation techniques would reduce evaporation of water in the process. ${ }^{12}$ Besides, the problem of inefficiency in use of irrigation water should be addressed through introduction of water-saving farming practices and crops [25]. Existing studies also suggest for treatment of waste water for its reuse in crop production [17]. However, strategic interventions designed in specific to landholding size would be crucial for this purpose [64]. There is also a need for judicious use of chemical fertilizers as their excessive use raises requirement of sufficient water causing further pressure on groundwater level. Besides,

\footnotetext{
12 However, the choice of irrigation system is influenced by its potential impact as well [34].
}

excessive use of chemical fertilizers can also reduce soil fertility in the long run [63].

Often it is suggested that the policy of supplying subsidized/free electricity for irrigation should be reviewed and the farmers should be guided to follow proper agronomic practices to avoid indiscriminate and irrational use of water and other inputs [67]. This requires integration of the decision support systems with government policies, geographical information systems and information technology [16]. Decisions should also be based on detailed information about users, water usage, groundwater extraction, aquifer conditions and depth of groundwater and its quality. Besides, successful implementation of policies should be reflected in potential gains [56].

\subsection{Scenario building for sustainable agricultural intensification}

As such, this paper also attempts to build alternative scenarios for policy inputs through FCM. Application of FCMs as a simulation tool in scenario planning can aid in the visualization and evaluation of possible scenarios in a problem domain. Evaluation of a scenario is facilitated through the analysis of state changes that the factors undergo in the corresponding FCM at each time step. Its ability to learn from past experience enables an FCM to discover any missing causal links between factors in the scenario. Scenario planning offers a framework for developing more resilient ecological policies to counter such situations where there is uncontrollable, irreducible uncertainty [83].

It is well recognized that, although its share in GDP has decreased over time, a large section of the country's workforce is still engaged in agriculture for their livelihoods $[80] .{ }^{13}$ Although the policies in the past broadly aimed at accelerating growth of the sector, conservation of critical natural resources including water, land and biodiversity lacked adequate emphasis causing serious concerns about sustainability of the growth process. This is alarming given that the contemporary development initiatives have led to excessive exploitation of natural resources in many countries [58]. The problem appears to be very critical in Indian context due to existence of many small landholder farmers, declining investment, sluggish technological advancement and depletion of important natural resources [32].

According to the experts and different stakeholders, major components of groundwater dynamics are rainfall variations, groundwater recharge, surface water irrigation,

\footnotetext{
13 Such prevalence of disguised employment has reduced labor productivity in the sector leading to relatively higher incidence of poverty in rural India (Sharma [75]).
} 
Table 7 Summary of FCM statistics. Source By authors (using mental modular) based on [41]

\begin{tabular}{ll}
\hline FCM properties & Value \\
\hline Total number of components & 25 \\
Total number of connections & 44 \\
Extent of density & 0.073333 \\
Number of connections per component & 1.76 \\
Number of driver components & 5 \\
Number of receiver components & 1 \\
Number of ordinary components & 19 \\
Complexity score & 0.2 \\
\hline
\end{tabular}

well irrigation, crop diversification, technology, GSDP, government expenditure, user group participation, yield, fertilizer use, groundwater level, policies and ecosystem services. Further, the panel data modeling suggests that irrigation and crop diversification have significant influence on cropping intensity. Accordingly, an attempt is been made here to model the dynamics of sustainable intensification in Indian agriculture using the FCM for building probable scenarios. This is based on inter-relationships across different factors influencing farming practices.

Based on Özesmi and Özesmi [55], Table 7 provides a summary of the FCM statistics. Given the number of variables, the presence of more concepts implies larger components. This paper uses 25 components. Higher number of connections (total 44 connections here) between the variables indicates larger degree of interactions between the components. Further, higher density stands for potentially stronger management policy.

Furthermore, the ratio of receiver to transmitter variables shows the outcomes of the driving forces. The complexity score stands for the complex systems of thinking. Components in receiving functions are influenced by other components, though they do not have any impact. Further, the receiving components indicate how many concepts are affected by others. Besides, the degrees (both in and out degrees of the components) and their centralities are reflected in Table 8. According to Gray et al. [23], absolute value of overall influence and that of individual concept imply total impact in the system and importance of individual concepts, respectively. A higher value here means greater importance or impact.
Table 8 In degree, out degree, centrality and type of concepts in the FCM. SourceBy authors (using mental modular) based on [41]

\begin{tabular}{|c|c|c|c|c|}
\hline Type & Component & In degree & Out degree & Centrality \\
\hline \multirow[t]{19}{*}{ Ordinary } & Private investment & 0.25 & 0.5 & 0.75 \\
\hline & Ecosystem services & 0.75 & 0.25 & 1 \\
\hline & Policy & 0.25 & 0.75 & 1 \\
\hline & Farm size & 0.75 & 0.5 & 1.25 \\
\hline & Rainfall variations & 0.75 & 0.75 & 1.5 \\
\hline & GW recharge & 0.75 & 0.75 & 1.5 \\
\hline & Cash crop & 1.25 & 0.25 & 1.5 \\
\hline & Subsidy in inputs & 0.5 & 1.25 & 1.75 \\
\hline & Modernization in agriculture & 0.5 & 1.5 & 2 \\
\hline & Land productivity & 1.25 & 0.75 & 2 \\
\hline & Technology & 1.25 & 0.75 & 2 \\
\hline & Crop diversification & 0.5 & 1.75 & 2.25 \\
\hline & Surface water irrigation & 1.5 & 0.75 & 2.25 \\
\hline & Yield & 2 & 0.5 & 2.5 \\
\hline & Fertilizer consumption & 1.75 & 1 & 2.75 \\
\hline & Govt expenditure on agriculture & 1.25 & 1.5 & 2.75 \\
\hline & Well irrigation & 1.75 & 1 & 2.75 \\
\hline & Groundwater (GW) availability (level) & 2.25 & 1.25 & 3.5 \\
\hline & Irrigation intensity & 1.25 & 3 & 4.25 \\
\hline \multirow[t]{5}{*}{ Driver } & GW used in household and industry & 0 & 0.25 & 0.25 \\
\hline & Population & 0 & 0.5 & 0.5 \\
\hline & Local user group governance & 0 & 0.75 & 0.75 \\
\hline & GSDP in agriculture & 0 & 1.25 & 1.25 \\
\hline & Agro-climatic setup & 0 & 1.5 & 1.5 \\
\hline Receiver & Cropping intensity & 2.5 & 0 & 2.5 \\
\hline
\end{tabular}




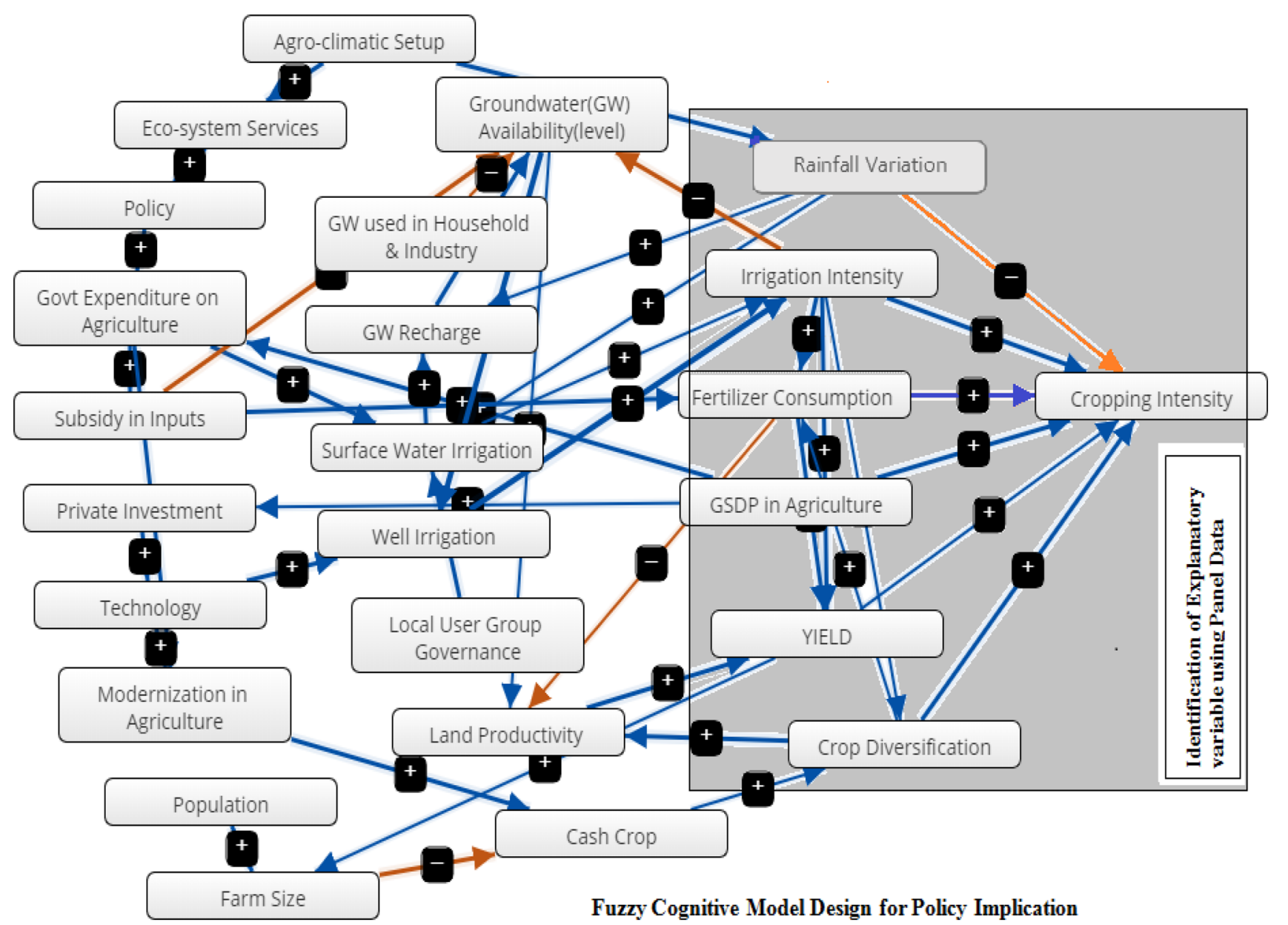

Fig. 6 Correlation inter-linkages among the parameters. Source: Designed by authors based on literature and field experiences

Notably, the causal relationship, magnitude and direction of relationships between the concepts are extracted from the literature and triangulated through visits to the study villages and interactions with the farmers, other stakeholders and experts along with the researchers associated with the SIAGI. The nature and complexities of the relationships are summarized in Fig. 6. Given the difficulties in quantifying many of these variables, we have designed a matrix and interlinking framework through the FCM using modular mental software based on information extracted from the literature, field visits, informal interactions and random discussion with different stakeholders, government reports and policy-related papers. The method is helpful because it enables one to have a broad understanding of the subject under investigation. The informal interactions and random discussion with different stakeholders not only generate information on collective views but also reveal a rich understanding of the experiences and beliefs that lie behind those views.

Overall, it is evident that the extent and nature of relationships vary across different pairs of variables. Besides, intersections of the arrows indicate interactions across the concepts and hence their overlapping relationships. Here, the blue and orange arrows show positive and negative causality between the concepts, respectively. Factors at the arrow points are the independent concepts, whereas the nock side factors are the dependent ones. The values of the weight (causality) determine the breadth of the arrows.

This paper designs the policy implications for sustainable intensification in agriculture in three steps. First, extensive literature review covering the above-mentioned aspects in both Indian and global context is carried out to frame the initial conceptual model. Next, significant explanatory variables identified through the panel data modeling and the insights gathered from the study villages are used to design the FCM. Finally, filtration of information and model validation are done in the presence of the famers, development practitioners and researchers in the project's workshops. The weights assigned to the coefficients imply weak (0.25), moderate (0.50), high (0.75) and very high (1.00) relationships between the concepts. These 

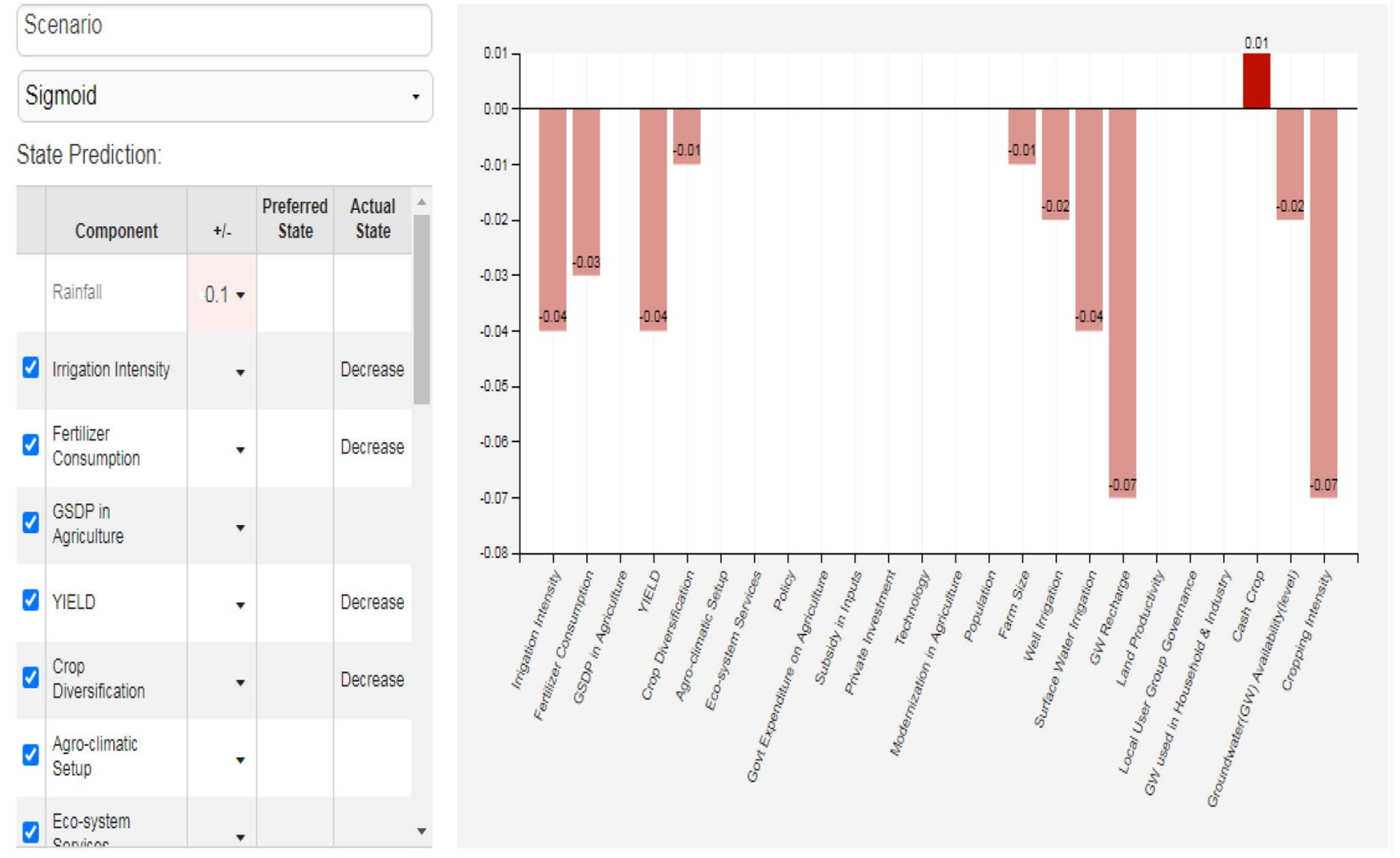

Source: By Authors (Using Mental Modular)

Fig. 7 Scenario I-Policy and other interventions by the government

three steps of the FCM are repeated several times until a suitable model is arrived at.

Based on the FCM framework, as presented in Fig. 6, three alternative scenarios are designed. Given that rainfall has decreased by over 10 percent in recent years and availability of groundwater for future cultivation is at the critical stage in the states like Punjab, Haryana, Odisha, etc., the first scenario (Fig. 7) is designed to understand the impact of policies and other interventions on intensification. This scenario captures over-extraction of groundwater with introduction of advanced technologies. The scenario shows that lack of irrigation facilities can force the farmers toward cultivation of the less water-intensive cash crops and as a result cropping intensity may decrease by around seven percent.

The Price Policy Commission for Kharif Crops of the Government of India (2015-16) recommended quantitative restrictions on use of water and electricity in agriculture. It also suggested encouraging the farmers toward use of drip irrigation and other agro-management techniques to increase production per single drop of water. ${ }^{14}$

\footnotetext{
$\overline{14}$ Enhancing efficiency of water in agriculture is crucial in areas with water scarcity [48].
}

Nevertheless, while improving efficiency and productivity of irrigation water is crucial [29, 72], private invest in such technologies requires well-defined water rights to incentivize the users [69]. Further, both the formal and informal institutional arrangements should be based on hydrological and economic conditions [9].

In order to overcome this problem of low intensification, government can invest on modernization of the sector through better access to efficient irrigation systems such as implementation of micro-irrigation projects, providing less water consuming seeds, etc. Nevertheless, there should be necessary corrective measures to address the potential decline in land productivity, groundwater recharge and surface water irrigation in the process. In addition to modernization of farming techniques, initiation of public-private partnerships and focus on enhancing farm productivity and resource efficiency, there is also a need for institutional innovation. Scenario II (Fig. 8) shows the state of agriculture after these measures are introduced. It is seen that there would be 3 percent improvement in cropping intensity if irrigation expands by more than 20 percent. Further, although there is a possibility of 20 percent increase in yield with improvements 


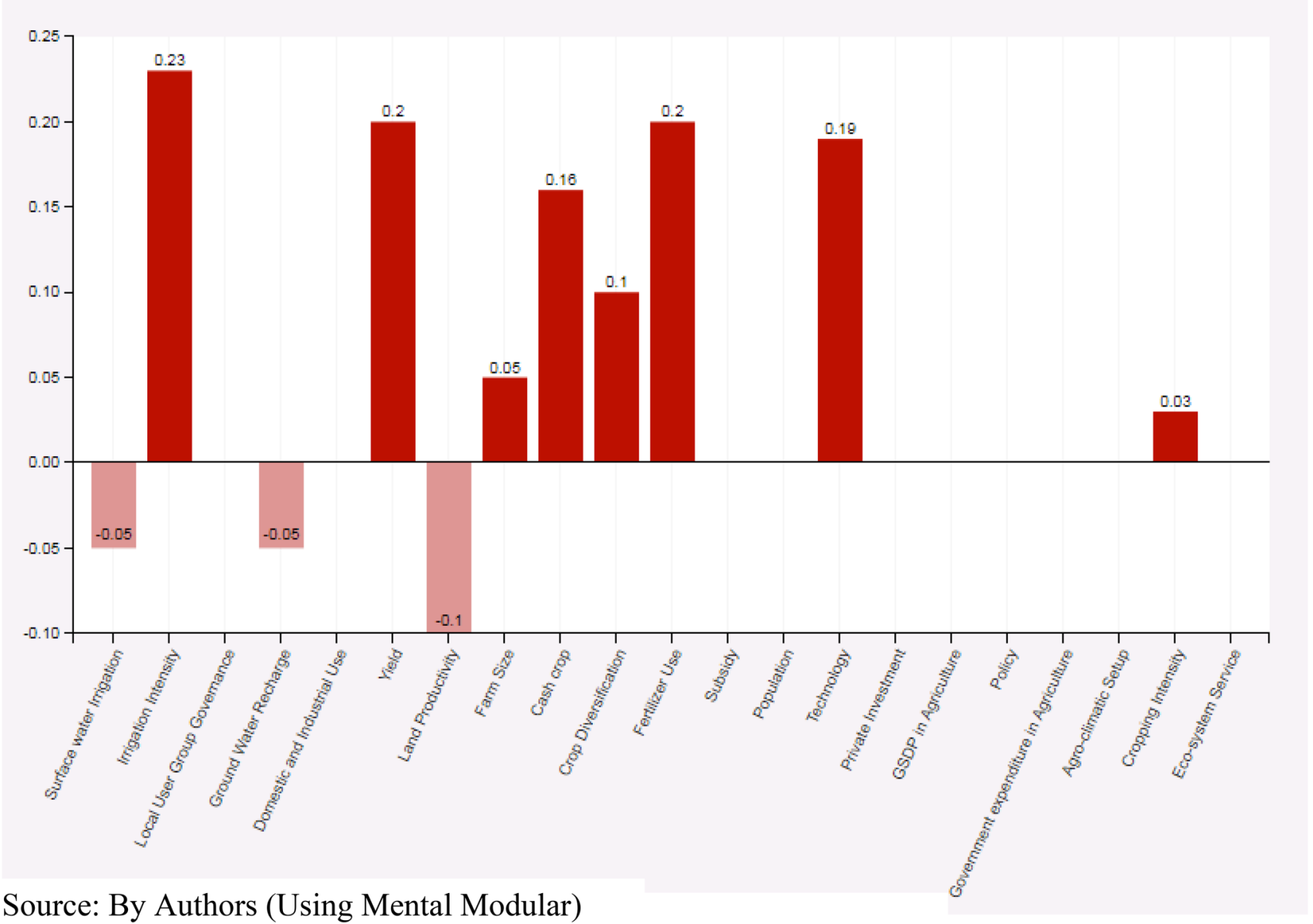

Fig. 8 Scenario II-Investment for modernization of agriculture

farming technologies, fertilizer use and crop diversification, it can also cause a negative growth in groundwater availability because of a decrease in surface irrigation.

Importantly, about 78 percent of available freshwater is diverted to agriculture $[47,49]$, whereas only 48 percent of total cropped area is under irrigation in India [52]. Further, paddy and sugarcane constitute one-fourth of the gross cropped area, consuming more than 60 percent of irrigation water and thus limiting its use for other crops $[1,79]$. Hence, efficient water management is necessary to balance irrigation potential with its appropriate utilization. This requires recalibration of cropping patterns toward maximization of crop production per unit of water used for irrigation. Such an approach would be crucial to increase food production, farm income and productive employment in water scarce regions [47].

Agricultural intensification is a development practice and agricultural sustainability is a strategy for agricultural development. Agricultural intensification is not against sustainability, and the former is not at all conservative. Both are the unity of the opposition. The contradiction was that the natural resources were depleted and the areas polluted with agricultural intensity, and so on. But organizations remain a double standard of response between agricultural and environmental consolidation. [87]. The sustainable intensification (SI) approach involves increasing food production from existing farms in ways that have a low impact on the environment and do not undermine our ability to continue producing food in the future [22]. Stability, without a focus on sustainability, has led to many problems around the world. SI does not mean that food production as normal and further improvements in sustainability, but rather re-evaluation of food systems not only to reduce environmental impacts but also to improve water and food flow and support rural economy and sustainable development [24].

Hence, for sustainability of agricultural intensification, there is a need for improvement of the potentiality of surface irrigation which would increase both intensity of irrigation and availability of groundwater. This is shown in scenario III (Fig. 9). Focus on surface irrigation may not necessarily raise the rate of growth of cropping intensity, 


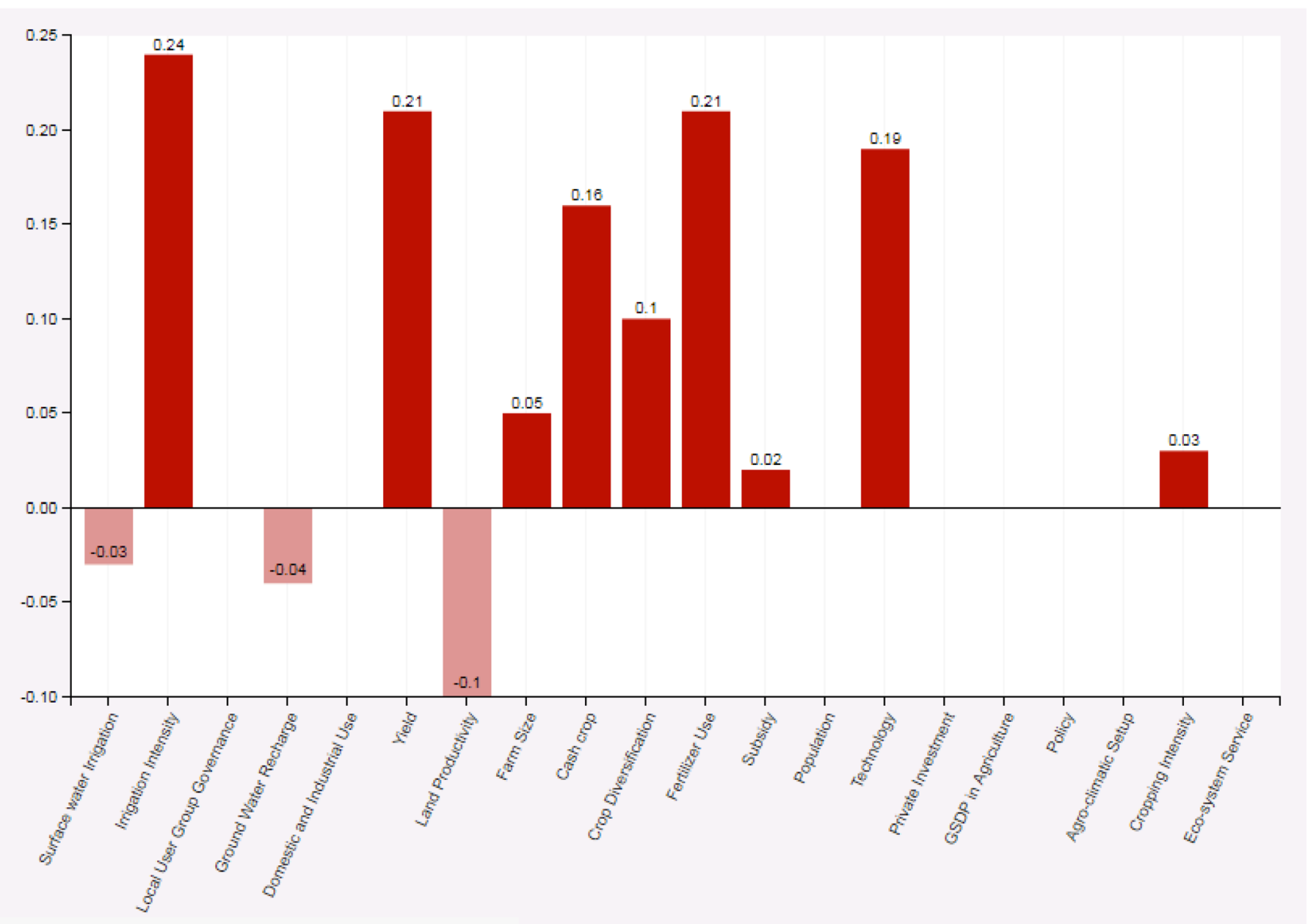

Source: By Authors (Using Mental Modular)

Fig. 9 Scenario III-Focus on surface irrigation

whereas improvement in irrigation intensity and groundwater potentiality may be marginal, but it is likely to make the process sustainable. This scenario essentially highlights the tradeoff between irrigation-based intensification in agriculture and its sustainability.

The three scenarios suggest that, given the enormous diversity of agro-climatic conditions, it is necessary to design separate norms and regulations to cater to the region-wise heterogeneities in irrigation-intensification relationships. It is seen that the well owners and those who buy water, use more of chemical fertilizers, labor and other inputs. It also appears that pump irrigation performs better in respect of intensification, input use and yield. As a result, proportion of land under groundwater irrigation is relatively high. On the other hand, higher benefits can be reaped on sustained basis from groundwater recharge and proper management of surface water through community participation. This approach can potentially foster changes in farming and water conservation practices. Moreover, policy interventions and farm planning in accordance with local agro-ecological conditions would be crucial for efficient groundwater management and its use in irrigation.

\section{Summary and conclusions}

This research attempts to model the relationships among agricultural intensification, irrigation intensity and crop diversification and their potential implications for groundwater dynamics in major Indian states. Using secondary data and carrying out panel data modeling, it is found that greater irrigation facilities, more use of chemical fertilizers, higher yield and diversified crop basket increase cropping intensity, whereas rainfall variations, share of GSDP in agriculture, have no significant impact on intensification. Thus, increase in cropping intensity requires greater irrigation facilities along with greater use of chemical fertilizers, but when it is based on groundwater, there are potential threats to sustainability of intensification. In this connection, the fuzzy 
cognitive modeling shows that appropriate policies and institutions toward modernization of agriculture and promotion of surface irrigation can improve groundwater potentiality and make intensification sustainable.

While there is a need for further detailed investigation of the impact of chemical fertilizers and rainfall variations on intensification, the findings of panel data and fuzzy cognitive modeling here provide important policy directions in respect of modernization of agriculture sector, surface water centric irrigation practices and efficient functioning of the water user groups along with cultivation of less water-intensive crops. More specifically, the findings suggest that there is a need for more rational use of groundwater along with storage of surface water and its use in irrigation to enhance future groundwater potentiality. There is also a need for enhancing efficiency of irrigation structures and water productivity in agriculture. The National Water Policy (NWP) also focuses on optimizing the effectiveness of the existing irrigation systems. It is expected that appropriate incentives can potentially facilitate recharge of wells, whereas water neutral and water positive technologies and introduction of drip, sprinkler, and ridge and furrow irrigation can reduce its wastage.

The paper also finds that crop diversification enhances cropping intensity and helps in mitigating various production- and market-related risks. More importantly, diversification toward less water-intensive crops facilitates more rational use of water. Hence, there is a need for promoting appropriate diversification of crop basket. However, extent of intensification through crop diversification may be limited for the smallholder farmers, particularly when agriculture is a secondary source of livelihoods for them and there are times, skill, scale and capacity-related constraints to grow high-value cash crops.

Further, the policies should facilitate to restoration of the traditional water harvesting systems. Amid the advantages of various artificial refill techniques, groundwater recharge through percolation tanks, 30-40 model, hapa and contour trench is less expensive, particularly in respect of the preliminary construction costs. Although there exist several innovative structures in the country, many of them are silted up and their reuse requires cleaning of the earthen structures and promotion of participatory approach to management. Besides, water-saving microirrigation techniques should be introduced to reduce its uncontrolled use. Since the recent developments have enhanced focus on the socially marginal groups, primitive classes, landless laborers and smallholder farmers, the socio-technical practices relating to water conservation and agricultural intensification need to be strengthened to create alternative pathways for inclusiveness and sustainability in agricultural intensifications in the line of the Sustainable Development Goals (SDGs) of the United Nations.

Acknowledgement This paper is partly based on experiences and insights gathered from participation in the workshops, field visits and informal discussion with different stakeholders in connection with ongoing study 'Promoting Socially Inclusive and Sustainable Agricultural Intensification in West Bengal (India) and Bangladesh' (SIAGI) sponsored by the Australian Centre for International Agricultural Research (ACIAR), Government of Australia, and led by the CSIRO (Australia). We are thankful to the ACIAR for giving us an opportunity to be associated with the study and providing necessary funding for the same. We received useful comments and suggestions from Christian Roth (Project Leader), Wendy Merritt, Sarena Hamilton, Uday Bhaskar Nidomulu, V. Ratna Reddy and Niladri Sekhar Bagchi at different stages of writing this paper. We are also thankful to the anonymous referees for their valuable comments on the earlier version of the paper.

Author contributions Bidur Paria (Conceptualization: Equal; Formal analysis: Lead; Investigation: Equal; Methodology: Lead; Software: Equal; Validation: Lead; Writing - original draft: Equal), Amartya Pani (Conceptualization: Equal; Investigation: Equal; Data curation: Supporting; Formal analysis: Supporting; Methodology: Supporting; Visualization: Lead; Writing - original draft: Equal), Pulak Mishra (Conceptualization: Equal; Formal analysis: Supporting; Funding acquisition: Lead; Methodology: Supporting; Project administration: Lead; Supervision: Equal; Writing - review \& editing: Equal), Bhagirath Behera (Conceptualization: Equal; Formal analysis: Supporting; Funding acquisition: Supporting; Project administration: Supporting; Resources: Lead; Supervision: Equal; Writing - review \& editing: Equal).

\section{Compliance with ethical standards}

Conflict of interest The authors declare that they have no conflict of interest.

Open Access This article is licensed under a Creative Commons Attribution 4.0 International License, which permits use, sharing, adaptation, distribution and reproduction in any medium or format, as long as you give appropriate credit to the original author(s) and the source, provide a link to the Creative Commons licence, and indicate if changes were made. The images or other third party material in this article are included in the article's Creative Commons licence, unless indicated otherwise in a credit line to the material. If material is not included in the article's Creative Commons licence and your intended use is not permitted by statutory regulation or exceeds the permitted use, you will need to obtain permission directly from the copyright holder. To view a copy of this licence, visit http://creativecommons .org/licenses/by/4.0/.

\section{References}

1. Asawa GL (2008) Irrigation and water resources engineering. New Age International (P) Ltd., New Delhi

2. Aggarwal PK (2008) Global climate change and Indian agriculture: impacts, adaptation and mitigation. Indian J Agric Sci 78(11):911

3. Ayanwale AOS (2014) Demand, Supply Response and Preference Switch for Rice in Nigeria (Doctoral dissertation) 
4. Acharya SS (2015) Second phase of agricultural marketing reforms and research issues. Indian J Agri Mark 29(2):41-49

5. Amjath-Babu TS, Kaechele $\mathrm{H}$ (2015) Agricultural system transitions in selected Indian states: What do the related indicators say about the underlying biodiversity changes and economic trade-offs? Ecol Ind 57:171-181

6. Ahmed MT, Bhandari H, Gordoncillo PU, Quicoy CB, Carnaje GP (2015) Diversification of rural livelihoods in Bangladesh. J Agric Econ Rural Develop 2(2):32-38

7. Babcock RC, Bustamante RH, Fulton EA, Fulton DJ, Haywood MD, Hobday AJ, Vanderklift MA (2019) Severe continental-scale impacts of climate change are happening now: extreme climate events impact marine habitat forming communities along $45 \%$ of Australia's coast. Front Mar Sci 6:411

8. Binswanger HP, Deininger K, Feder G (1995) Power, distortions, revolt and reform in agricultural land relations. Handb Dev Econ 3:2659-2772

9. Bhattarai $M$, Narayanamoorthy $A(2003)$ Impact of irrigation on rural poverty in India: an aggregate panel-data analysis. Water Polic 5(5-6):443-458

10. Behera B, Mishra P (2007) Acceleration of Agricultural Growth in India: Suggestive Policy Framework. Econ Political Weekly 42(42):4268-4271

11. Barakat A, Ennaji W, El Jazouli A, Amediaz R, Touhami F (2017) Multivariate analysis and GIS-based soil suitability diagnosis for sustainable intensive agriculture in Beni-Moussa irrigated subperimeter (Tadla plain, Morocco). Model Earth Syst Environ 3(1):3

12. CGWB Groundwater Year Book 2012-2013 (Ministry of water resources, Government of India, 2014)

13. Central Water Commission (CWC) (2014) Water and related statistics. ministry of water resources: New Delhi, India

14. Chen B, Han MY, Peng K, Zhou SL, Shao L, Wu XF, Chen GQ (2018) Global land-water nexus: agricultural land and freshwater use embodied in worldwide supply chains. Sci Total Environ 613:931-943

15. Chowdhury K, Behera B (2018) Is declining groundwater levels linked with the discontinuity of traditional water harvesting systems (tank irrigation)? empirical evidence from West Bengal, India. Groundwater Sustain Develop 7:185-194

16. FAO (2010) FAO cuts wheat production forecast but considers supplies adequate http://www.fao.org/news/story/tr/ item/44570/icode/en/, accessed Jan 2011

17. Feigin A, Ravina I, Shalhevet J (2012) Irrigation with treated sewage effluent management for environmental protection. Springer, Berlin

18. FAO (2014) Building a common vision for sustainable food and agriculture - principles and approaches. Rome, Italy: FAO. Retrieved from http://www.fao.org/3/a-i3940e.pdf

19. Government of India (2011) Key indicators of employment and unemployment in India 2009-10, NSS 66th round (July 2009to June 2010), National statistical office, national sample survey office, ministry of statistics and programme implementation. Govt. of India, New Delhi

20. Ghosh BK (2010) Growth and variability in the production of crops in West Bengal Agriculture. Trends Agric Econ 3(3):135-146

21. Government of India (2014) Report of the expert group to review the methodology for measurement of poverty, Planning commission, June

22. Garnett T, Appleby MC, Balmford A, Bateman IJ, Benton TG, Bloomer P, Godfray HCJ (2013) Sustainable intensification in agriculture: premises and policies. Science 341(6141):33-34
23. Gray SA, Zanre E, Gray SR (2014) Fuzzy cognitive maps as representations of mental models and group beliefs: in Fuzzy cognitive maps for applied sciences and engineering. Springer, Berlin

24. Gadanakis Y, Bennett R, Park J, Areal FJ (2015) Evaluating the sustainable intensification of arable farms. J Environ Manage 150:288-298

25. Gill SS, Nehra KS (2018) Subsidy and Efficiency of Groundwater Use and Power Consumption in Haryana. Econ Polit Weekly 53(50):33

26. Hansen JW (1996) Is agricultural sustainability a useful concept? Agric Syst 50(2):117-143

27. Haque T (2003) Reforms for Agricultural Growth and Rural Development. Econ Political Wkly 38(48)

28. Halder JC (2019) Modeling the effect of agricultural inputs on the spatial variation of agricultural efficiency in West Bengal India. Model Earth Syst Environ 5(3):1103-1121

29. Haile AT, Alemayehu M, Rientjes T, Nakawuka P (2020) Evaluating irrigation scheduling and application efficiency: baseline to revitalize Meki-Ziway irrigation scheme Ethiopia. SN AppISci 2(10):1-12

30. Jabeen M, Ahmad Z, Ashraf A (2020) Predicting behaviour of the Indus basin aquifer susceptible to degraded environment in the Punjab province Pakistan. Model Earth Syst Environ 6(3):1633-1644

31. Jetter AJ, Kok K (2014) Fuzzy cognitive maps for futures studies-a methodological assessment of concepts and methods. Futures 61:45-57

32. Joshi PK, Pangare V, Shiferaw B, Wani SP, Bouma J, Scott C (2004) Watershed development in India: synthesis of past experiences and need for future research. Indian J Agric Econ 59(3):303-319

33. Kar G, Singh R, Verma HN (2004) Alternative cropping strategies for assured and efficient crop production in upland rainfed rice areas of eastern India based on rainfall analysis. Agric Water Manag 67(1):47-62

34. Kundzewicz ZW et al (2007) Freshwater resources and their management, in Climate Change 2007: Impacts, Adaptation and Vulnerability-Contribution of Working Group II to the Fourth Assessment Report of the Intergovernmental Panel on Climate Change, pp 174-210, Cambridge University Press, Cambridge, UK

35. Kumar MD (2008) Managing water in the face of growing scarcity, inequity and declining returns: exploring fresh approaches. Proceedings of the 7th Annual Partners Meet, IWMI TATA Water Policy Research Program, ICRISAT, Patancheru, Hyderabad, India, 2-4 April 2008. vol 1

36. Kafetzis A, Neil Mc, loanna M (2010) Using fuzzy cognitive maps to support the analysis of stakeholders' views of water resource use and water quality policy studies in fuzziness and soft computing, Doi: https://doi.org/10.1007/978-3-642-03220-2_16

37. Kottas TL, Boutalis YS, Christodoulou MA (2010) Fuzzy cognitive networks: adaptive network estimation and control paradigms, a. Stud Fuzziness Soft Comput 247:89-134

38. Kumar S, Gupta S (2015) Crop diversification towards high-value crops in India: A state level empirical analysis. Agric Econ Res Rev. https://doi.org/10.5958/0974-0279.2016.00012.4

39. Kumar SGA (2016) Performance of irrigation and agricultural sector in Orissa: an analysis of missing links. Indian Res J ExtenEduc 10(2):48-54

40. Kareemulla K, Venkattakumar R, Samuel MP (2017) An analysis on agricultural sustainability in India. CurrSci. https://doi. org/10.18520/cs/v112/i02/258-266

41. Kokkinos K, Lakioti E, Papageorgiou E, Moustakas K, Karayannis V (2018) Fuzzy cognitive map-based modeling of social 
acceptance to overcome uncertainties in establishing waste biorefinery facilities. Front Energy Res 6:112

42. Kumar S, Sidana BK (2019) Input-use efficiency of adopters of climate resilient technologies in paddy and wheat crop in Punjab agriculture. Clim Change Environ Sustain 7(1):51-60

43. Kyei-Mensah C, Kyerematen R, Adu-Acheampong S (2019) Impact of Rainfall variability on crop production within the Worobong ecological area of Fanteakwa district. AdvAgri, Ghana. https://doi.org/10.1155/2019/7930127

44. Lindgren M, Bandhold H (2003) Scenario planning. Palgrave, London

45. Laha M, Arambagh W (2017) Irrigation and groundwater hazards in India. Transactions 39(2):237

46. Mandal R (2014) Flood, cropping pattern choice and returns in agriculture: a study of Assam plains, India. Econ Anal Policy 44:333-344

47. Molden D, Oweis T, Steduto P, Bindraban P, Hanjra MA, Kijne J (2010) Improving agricultural water productivity: Between optimism and caution. Agric Water Manag 97(4):528-535

48. Mohammadi J, Esmaeelnejad L, Ramezanpour H (2016) Land suitability assessment for optimum management of water consumption in precise agriculture. Model Earth Syst Environ 2(3):162

49. Milner J, Joy EJ, Green R, Harris F, Aleksandrowicz L, Agrawal S, Dangour AD (2017) Projected health effects of realistic dietary changes to address freshwater constraints in India: a modelling study. The Lancet Planetary Health 1(1):e26-e32

50. Mohan S (2017) Indian policy and development. McGraw-Hill Education, New York

51. Mithiya D, Mandal K, Datta L (2018) Trend, pattern and determinants of crop diversification of small holders in West Bengal: a district-wise panel data analysis. J Develop Agri Econ 10(4):110-119

52. Narayanamoorthy A (2004) Drip irrigation in India: can it solve water scarcity? Water Policy 6(2):117-130

53. Nelson GC et al (2010) Food Security, Farming, and Climate Change to 2050: Scenarios, Results, Policy Options. International Food Policy Research Institute, Washington, DC

54. O'Connell PF (1991) Sustainable agriculture. In: Agriculture and the Environment: The 1991 Yearbook of Agriculture. US Government Printing Office, Washington, DC

55. Özesmi U, Özesmi SL (2004) Ecological models based on people's knowledge: a multi-step fuzzy cognitive mapping approach. Ecol Model 176(1-2):43-64

56. Oster JD, Wichelns D (2014) EW Hilgard and the history of irrigation in the San Joaquin Valley: Stunning productivity, slowly undone by inadequate drainage. In salinity and drainage in San Joaquin Valley, California. Springer, Dordrecht

57. Planning Commission. (2008). Eleventh five year plan 2007-12. Volume-I. Inclusive growth

58. Patra S, Mishra P, Mahapatra SC, Mithun SK (2016) Modeling impacts of chemical fertilizer on agricultural production: a case study on Hooghly district, West Bengal India. Model Earth Syst Environ 2(4):1-11

59. Perry C, Steduto P, Karajeh F (2017) Does improved irrigation technology save water? A review of the evidence. FAO, Cairo. http://www.fao.org/3/b-i7090e.pdf

60. Papageorgiou El, Papageorgiou K, Dikopoulou Z, Mouhrir A (2018) A web-based tool for Fuzzy Cognitive Map Modeling, presented at the 9th International Congress on Environmental Modelling and Software. (iEMSs), Fort Collins, CO

61. Pradhan A, Sathanandhan R, Panda AK, Wagh R (2018) Improving household diet diversity through promotion of nutrition gardens in India. Am J Food Sci Nutr 5:43-51
62. Pani A, Mishra P (2019) Hapa irrigation for promoting sustainable agricultural intensification: experience from Bankura district of India. GeoJournal. https://doi.org/10.1007/s10708-019-10056 $-8$

63. Perera KHK, Udeshani WAC, Piyathilake IDUH, Wimalasiri GEM, Kadupitiya HK, Udayakumara EPN, Gunatilake SK (2020) Assessing soil quality and soil erosion hazards in the Moneragala District Sri Lanka. SN ApplSci 2(12):1-13

64. Qureshi AS, Gill MA, Sarwar A (2010) Sustainable groundwater management in Pakistan: challenges and opportunities. Irrig Drain J IntCommIrrig Drain 59(2):107-116

65. Rosegrant MW, Agcaoili SMC, Perez ND (1995) Global food projections to 2020 implications for investment. Diane publishing, US

66. Rasul G, Thapa GB (2003) Sustainability analysis of ecological and conventional agricultural systems in Bangladesh. World Dev 31(10):1721-1741

67. Rahman S (2010) Women's labor contribution to productivity and efficiency in agriculture: empirical evidence from Bangladesh. J Agric Econ 61(2):318-342

68. Raina S (2012) Rain-fed agriculture for an egalitarian and sustainable future: an input to FAO' country programming framework for India. Food and agricultural organization, New Delhi

69. Rasmussen LV, Coolsaet B, Martin A, Mertz O, Pascual U, Corbera E, Ryan CM (2018) Social-ecological outcomes of agricultural intensification. Nat Sustain 1(6):275

70. Retrieved from https://icar.org.in/content/dare-icar-annua I-report-2018-19 on Jun, 2020

71. Singh SD, Gupta JP, Singh P (1977) Water economy and saline water use by drip irrigation. Agron J 70:948-951

72. Saleth RM, Namara RE, Samad M (2003) Dynamics of irrigationpoverty linkages in rural India: analytical framework and empirical analysis. Water Policy 5(5-6):459-473

73. Singh NP, Kumar R, Singh RP (2006) Diversification of Indian agriculture composition, determinants and trade implications. Agri Econ Res Rev 19(347-2016-16742):23-36

74. Schoengold K, Zilberman D (2007) The economics of water, irrigation, and development. Handb Agric Econ 3:2933-2977

75. Sharma A (2007) The changing agricultural demography of India: evidence from a rural youth perception survey. Int J Rural Manag 3(1):27-41

76. Sharma VP (2007) India's agrarian crisis and smallholder producers' participation in new farm supply chain initiatives: a case study of contract farming

77. Shiferaw B, Hellin J, Muricho G (2011) Improving market access and agricultural productivity growth in Africa: what role for producer organizations and collective action institutions? Food Sec 3(4):475-489

78. Salmeron JL (2012) Fuzzy cognitive maps for artificial emotions forecasting. Appl Soft Comput 12(12):3704-3710

79. Sharma VP (2012) Accelerating agricultural development for inclusive growth: strategic issues and policy options. Vikalpa 37(1):1-18

80. Suresh A, Mathur VC (2016) Export of agricultural commodities from India: Performance and prospects. Indian J Agric Sci 86(7):876-883

81. Struik PC, Kuyper TW (2017) Sustainable intensification in agriculture: the richer shade of green. Rev Agronomy Sustain Develop 37(5):1-15

82. Suhag R (2016) Overview of ground water in India. PRS

83. Sujamol S, Ashok S, Krishnakumar U, Anoob CS (2018) A genetically optimized method for weight updating in fuzzy cognitive maps. In 2018 international conference on emerging trends and 
innovations in engineering and technological research (ICETIETR) (pp 1-5). IEEE

84. Vaidyanathan A (2006) India's water resources: contemporary issues on irrigation. Oxford University Press, New Delhi

85. VanVliet M, Kok K, Veldkamp T (2010) Linking stakeholders and modelers in scenario studies: the use of Fuzzy cognitive maps as a communication and learning tool. Futures 42(1):1-14

86. World Bank (2010) World Development Report 2008. Agriculture for Development, Washington, DC
87. Zhang W, Ricketts TH, Kremen C, Carney K, Swinton SM (2007) Ecosystem services and dis-services to agriculture. Ecol Econ 64(2):253-260

Publisher's Note Springer Nature remains neutral with regard to jurisdictional claims in published maps and institutional affiliations. 